\title{
MIZRAKLI İLMİHÂL KÜLTÜRÜ YA DA GELENEKSEL DİN ALGISINI BESLEYEN POPÜLER DİNDARLIĞIN ETKİNLİK ALANLARI ÜZERINNE BAZI TESPITLER
}

Namık Kemal OKUMUŞ*

$\ddot{\mathbf{O} z}$

İlmihâller, halkın din anlayışını şekillendiren önemli eserlerden sayılmaktadır. Bu yüzden, ilmihâllerin sıradan halka ne verdiğine dikkat edilmelidir. Halka dinini öğretmek için kaleme alınmış olan ilmihâllerin insan yetiştirme içerikleri esasında inanç, ibadet ve ahlâk temeli üzerinde şekillenmelidir. Mevcut ilmihallerde iman ve ibadet içeriklerinin verilmesine karşın, ahlâk kazanımlarına aynı oranda değinilmediği görülmektedir. Sadece Osmanlı Toplumu'nun değil, Cumhuriyet sonrası Türk Toplumu'nun da dinini öğrendiği eserlerin başında gelen Mızraklı İlmihal örneği, bu konuda dikkate değerdir. Bu sebeple, çalışma süresince popüler dindarlığın temel eserlerden olan ilmihâllerin ahlâk kazanımlarıyla olan yakın ilişkisine değinilecektir.

Anahtar kelimeler: mizraklı İlmihâl, popüler dindarlık, din, ahlâk, toplum, değer.

\section{SOME DETERMINATIONS ON DOMAIN OF POPULAR PIETY REINFORCING TRADITIONAL RELIGION PERSPECTIVE OR CULTURE OF MIZRAKLI ILM-IHÂL}

\begin{abstract}
Catechism is considered the major works that shaped the public's understanding of religion. Therefore, it should be noted what's given by catechism to ordinary people. Catechism of the ring, which was written to teach religious beliefs on the basis of human culture content must be formed on the basis of worship and morality. Although given the current ilmihals the content of faith and worship, there has not been mentioned in the same proportion to the moral gains. It's not just the Ottoman society, the example of Mizraklı İlm-ihâl as one of the main studies that the Republican Turkish society had benefits to learn about religion, is noteworthy in this regard. Therefore, during the study, as the fundamental works of popular piety, catechism will be referred to the relationship between morality.
\end{abstract}

Keywords: Mizrakli ilm-ihâl, popular piety, religion, morality, society, moral.

\section{Giriş}

Bilindiği gibi İslâmî emir ve yasakların ana gayesi, ahlâklı bir toplum üretebilmektir. Bunun içindir ki ilgili gayenin tahakkuku için inanç, ibadet ve

Makale gönderim tarihi: 06.06.2017, kabul tarihi: 01.11.2017

Doi: $10.26791 /$ sarkiat.319355

* Doç. Dr., Recep Tayyip Erdoğan Ünv. İlahiyat Fak. 
çeşitli ritüeller önerilmiştir. Bu ritüellerin inanç ve ibadet ilkeleri gözetilerek hayata geçirilmesi gerekmektedir. İnanç boyutu üzerinden metafizik alandaki inşasını tamamlayan insan, ibadetler sayesinde kişisel ve toplumsal hayatında eğitileceği davranış modelleri üzerinden kişilik inşa sürecine dâhil olmaktadır. Yani inanç ve ibadetler bireyin kişilik inşasında önemli parametreleri barındırmaktadır. Bu adım, hem gerekli, hem de onun eğitiminin mutlak bir parçasıdır. Özellikle inanç ve ibadet uygulamaları üzerinden geliştirilmiş olan ahlâkî kazanımları yakalamış olan birey, içerisinde yaşamakta olduğu dünyanın gidişine da olumlu katkılarda bulunabilecektir. Bu anlamda İslâm vahyi, iman, ibadet ve ahlâk kazanımı üzerinden Müslüman bireyi eğiten bütüncül bir dünya görüşünü de sahibi için öngörmektedir. Zira kişi ve toplumlar, genel olarak inanç ve ibadet hayatı üzerinden değil, inanç ve ibadetin hayata yansıyan yönü olan ahlâkî kazanımlar üzerinden ilişki kurmaktadır. O yüzdendir ki inanç, ibadet ve ahlâk, tevhidî projenin üç ayağını oluşturmaktadır. Namaz, oruç, hac vb. ibadetlerin yanı sıra, dürüst olmak, dengeli, sakin, âdil ve paylaşımcı bir hayat sürmek de bu yapının eğitici fonksiyonlarıdır. Bu yüzdendir ki ibadetlerin birincil kazanımı, sosyal hayatta görülebilen ahlâkî kazanımlar üzerinden tanımlanmaktadır. Dahası ibadetler, ahlâk merkezli kişisel adımları destekleyen ve tutarlı davranış modeli geliştiren bir temrin olarak kabul edilebilir. Bu aşamada denilebilir ki ilâhî irade nezdinde ibadetlerin kurgulanmasındaki gerçek amaç, sadece ibadet eden bir kişiliğin temini değil, ilgili ibadetler üzerinden ibadet ve inancın eğitmiş olduğu ahlâklı bir toplumsal yapıya kavuşmaktır.

Aynı şekilde ifade edilebilir ki, dinin gerçek amacı, sadece Yüce Allah'a inanan etkisiz bir bireyin temininden ziyade, Allah inancını temellük eden güçlü bir bireyin, bu inanç üzerinden O'nun koymuş olduğu düzenin idamesine yardımcı olabilecek bir değer alanı oluşturmasıdır. O nedenledir ki taabbudî kazanımlarda gerçek hedef, bütünüyle ahlâkî donanım olmalıdır. Mamafih ahlâk yoksunu bir inanç ya da ahlâkın etkisiz eleman olduğu bir ibadet hayatı, Tanrının amacının eksik anlaşılması demek olacağından, sonuçta bu eğilimin de kimseye yararı dokunmayacaktır. Belki de bu nedenden ötürü, dinî değerlerin kişisel gelişime katkısı ve ahlaklı bireyin inşası esnasında kişisel ve toplumsal önceliğimizin, Yaratıcı'nın hedeflemiş olduğu "ahlâklı birey ve toplum" modeli olması gerekmektedir. Bu hedefin başarılabilmesi için ise inanç ve ibadetler, Tanrı'nın hedeflemiş olduğu düzenin tahakkuku adına kişisel ve toplumsal değerlerin yerleşmesini sağlayan eğitim sürecinin basamak taşları olarak görülmelidir. Dahası, bu uygulamalar, dünya hayatında varlığın bütününe karşı şefkatli davranabilen iyi bir Müslümanın yetişmesi adına yeterli amaç değil, kişi ve toplumları bu hedefe taşıyan araç ve basamak değerler olarak kabul edilmelidir.

Bilindiği gibi geleneksel dindarlığın insan ve toplum algısının besleyen metinleri arasında öncelikli olarak ilmihâller gelmektedir. ${ }^{1} \mathrm{Bu}$ besleyicilik vasfının

\footnotetext{
${ }^{1}$ Geleneksel dindarlığın ölçülebilir formlarından olan pek çok ritüel, ilgili eserlerde ibadet formu olarak adeta bir "kutsal şemsiye" altına alınmıştır. Zira halkın geleneksel olarak kutladığı bu tür ritüeller, esasında onların dindarlığını artırıcı bir etmen olarak da görülmelidir. Buna mukabil olarak adı geçen kutsallık algısının İlmihal türü eserlerde sıkça işlenmesi ise, dindar halkın o uygulamalara karşı olan iştiyakını artırdığı gibi, bununla birlikte o uygulamaların dinin içinden bir 
ümmetin din algısı üzerinde derin izler bırakmış olduğu, hatta din denilince öncelikli olarak insanın aklına ilmihâl bilgisinin geldiği de söylenebilir. İlmihâller, aynı zamanda din ve toplum anlayışımızın karakteristik yapısının temel öğesi mesabesindeki eserlerin başında gelmektedir. Dahası, bu eserlerin halkın dindarlık ölçeği üzerindeki etkisi, halk nezdinde din denilince anlaşılan şeyin "neliği" konusundaki geri bildirimlerden de anlaşılabilir durumdadır. Bugün itibariyle söyleyecek olursak, mevcut din anlayışının gerek öğretici konumundaki aktörler üzerinde, gerekse de öğrenici konumundaki kişileri üzerinde baskın izlerini görmek her daim mümkündür. Bu yüzdendir ki ilgili dinsel alg1 kişisel ve toplumsal süreçlerde göründügünden daha kuvvetli kökleri olan ve dinsel değişimin önündeki direnç noktalarından birisidir denilebilir. Diğer bir deyişle öğrenilmiş çaresizliğin başka bir şekli olan bu durumun değişmesi, vahyin yaşanan hayata yine ve yeniden dokunması için elzem bir durumu gerektirmektedir. Öyle ki geleneksel bilgiyi son derece önemseyen bu klâsik alg1, onu taşıyan sahibi üzerinde istendik değişimin gerçekleşmesi noktasında güçlü bir engel mesabesinde görülmektedir.

Müslümanlığının temel eserleri arasında sayılan ilmihâllerde yazım amaçlarına uygun olarak görülen her kazanım, değişmez bir ibadet formu altında sunulmaktadır. Sahibi için tefrik edici mahiyette olan bu durum, başkaları için ise yabancı bir hüviyet taşımaktadır. Bu yapıdan da ilmihâllerdeki bilgileri dinin kesin olarak emretmiş olduğu kutsal bilgi formunda gören bir anlayışın doğmuş olması, problemin tespiti babında ifade edilecek olursa, esas kaynaktan uzaklaşan bir din eğitim ve öğretiminin olduğunu göstermektedir. Dahası, bu tip eserlerin yazarları, zaman içerisinde yanlış ve hata yapmaz kişilikler olarak görülmeye başlandığı içindir ki, dinî konularda delil getirilirken sadece bu eserlerden yararlanılmaktadır. Bu şekliyledir ki halkın dindarlık ölçeğinde merkezî bir yerde duran eser ve müellifler, giderayak söylenilenin hakikat içermesi noktasından, söyleyenin daha değerli olarak görüldügü bir yaklaşım üzerinden nisbî bir kutsallık da kesbetmişlerdir. Hatta daha da ileri gidilerek bu eserler ve yazarları, bazen sade halk için sorgulanamaz bir yapıya da dönüşerek, mevcut dinî bilginin ender taşıyıcısı olmaları gereği üzerinden hakikatin değişmez ölçüsü hâline de gelmişlerdir.

İlmihâl dindarlığı denilen şey, ${ }^{2}$ esasında fikıh dindarlığının başka bir versiyonu olsa gerek. Fikıh dindarlığından kastımız, ibadet ve taatin amaç ve

pratik olarak algılanmasını da temin etmiş gibidir. Mesela daha ziyade Türk Müslümanlığının ananevî bir gösterge değeri olan "kutsal/mübarek geceler" formu buna örnek olarak verilebilir. (Kadir Gecesi, Arife, Fıtr/Ramazan Bayramı Günleri ve Geceleri, Kurban Bayramı Günü ve Geceleri, Mevlit Kandili Gecesi, Ber'at Kandili Gecesi, Miraç kandili Gecesi, Muharrem Ay1, Recep Ay1 ve Regaib Gecesi, Aşure Günü, Kutlu Doğum Günü Kutlamaları). Ayrıca, dinimizin son derece dikkatli bir şekilde önem vermiş olduğu ağız ve diş temizliğinin o döneme ait bir aparatı olan misvakın tıbbî faydalarının işlendiği bölümler, ilmihal türü eserlerde şekil unsurunun hâlâ esasın yerini aldığını da göstermektedir. Bkz. İ. Hakkı Uca, Delil ve Kaynaklarıyla Büyük Kadın İlmihâli, İstanbul 2003; Hasan Yavaş, Rehber İlmihâl, İstanbul 2009; Nihat Temel, Kur'an Aydınlı̆̆ında Müslümana Yol Haritası, İstanbul 2006.

${ }^{2}$ Kanaatimizce Müslüman kültür içerisinde etkin bir yer edinmiş olan "ilmihâl dindarlı̆̆l"nı en doğru bir şekilde dile getirmiş olan ifadelerden birisi Necip Fazıl'ın şu dizeleridir: "Yandl kitaplarım, ne garip bir hâl oldu! Sonunda bana kalan, yalnız ilmihâl oldu." Necip Fazıl 
kazanımlarından çok, icra ediliş veya formel şekilleri üzerinde yoğunlaşan bir dindarlıktır. Zira bu tür dindarlıkta aslolan şey, bir şeyin kuralları gözetilerek yapılmış olmasıdır. Diğer bir deyişle ilgili dindarlıkta şekilsel ölçüler her şeyden önceliklidir. Amaçlanan şey, bütünüyle bu olmasa da, bu yapıda öncelikli olarak dile getirilmiş olan şekilsel kazanımın tahkim edilmesi fikri, kişisel gelişimi temin eden takva boyutundan çok, daha alt katmanlardaki eksikleri kapatma ve ibadeti bozan-bozmayan unsurlar üzerinden detaylandırılmıştır. Önemsiz olduğundan değil ama gereğinden fazla önem verildiğini düşündügümüz bu çeşit dindarlıkta, tıpkı mezhebin din olarak algılandığı halk dindarlığı nezdinde olduğu veçhile, kendisi gibi ibadet yapmayanların öteki olarak görülme tehlikesi vardır. Bu durumun ise Müslümanların tevhidine bir katkısının olmayacağı aşikârdır. Zira "şeklî detayların" "öz"ün yerine geçtiği her dindarlık ölçeğinde, ibadetin amacı ve kazanımını tespit edecek olan "akll" ve "şuur" yerini "taklide" ve "tekrara" brrakmaktadır. Neticede ise bu dindarlık modeli "geleneksel dindarlı"" tanımlamasını hak etmiş olmaktadır.

Denilebilir ki sorunun çözümü de kendi içerisinde saklı bir vaziyette bulunmaktadır. Mevcut dinî algının ahlâkî kazanım yönüne doğru evrilmesi ve bu sayede şekilcilikten kurtulup özsel kazanımlara yönelmesi, istenilen verimin elde edilmesini kolaylaştıracaktır. Belki de o zaman insanlık için çıkarılmış olan "mutedil/dengeli bir ümmet" vasfi, ${ }^{3}$ bizim için daha bir anlamlı olacaktır. Başkalarının kurtuluşu için "empati yapabilen", bir ahlâk modeli olarak tanımlanmış olan İslâm Dini, uygulayıcılar eliyle kendi içerisinde öteki yaratmayı bir tarafa bırakmalıdır ki tutarlılık üzerinden hayata dokunmayı başarabilsin.

\section{I-Popüler Dindarlığın Öncelikleri ve Ahlâkî Kazanım Beklentisi}

\section{1-Problemin Tanımlanması}

Bugün ülkemizde halk dindarlığının başucu eserlerinden olan Ömer Nasuhi Bilmen'in "Büyük Íslâm İlmihâli" adlı eseri alanında hâlâ bir klâsik olarak durmaktadır. Adı geçen eser, gerek kendinden önceki ilmî geleneği, gerekse de

Kısakürek, İman ve Íslâm Atlası, İstanbul 1981, s. 6. Beşerin din ve toplum algısına ilmihal kültürü o denli yerleşmiştir ki sadece bizde değil, batıda da aynı isimle eserler kaleme alınmıştır. Nitekim Batı Felsefesi'nin önemli temsilcilerinden birisi olan Auguste Comte'un "Le Catéchisme Positiviste" adlı eseri, dilimize "Pozitivizm Illmihali" şeklinde çevrilmiştir. Bkz. Auguste Comte "Pozitivizm İlmihali", İstanbul 1986.

${ }^{3}$ Bakara, 2/143.

${ }^{4}$ Filozofların ahlâkın kaynağı dedikleri erdem, "sana yapılmasını istemediğin bir şeyi başkasına yapmaman" ilkesidir. Nitekim Hz. Peygamber de bu minvâl üzere: "Kendisi için istediğini başkası için de istemedikçe kişinin imanı olgunlaşamaz." (Buharî, Iman, 7; Müslim, Iman, 71) buyurarak, başkasının iyiliğini düşünme ahlâkî kazanımı üzerinden kâmil bir insan portresi çizmiştir. Aynı şekilde Kur'an-1 Kerim'deki bazı olaylarda empatik değer üzerinden ilişki kurulması salık verilmektedir. Meselâ, Hz. İbrahim'in babası ve kavminin içinde bulunduğu durumu anlama çabası, yaşlılara küçükken bizleri baktığı için ihtiyarlıklarında onlara bakmanın gereği, verilene razı olmanın ve adalete rıza göstermenin gerekliliği ve kendisi de bir yetim olan elçi üzerinden yetimleri koruyup kollamanın önerilmesi gibi uygulamalar, ötekini anlamak için bulunmaz fırsatlar olarak kabul edilmelidir. Bkz. Nisa, 4/9, İsra, 17/23-25, Kıyâmet, 75/2, Mutaffifîn, 83/1-4, Duhâ, 93/5-11. 
kendinden sonraki ilmihâl yazım geleneğini ifade eden güçlü bir eser olarak görülmelidir. Ayrıca devlet dindarlığının kurumsal merkezi olan Diyanet'in bu ilmihâl üzerinden özellikle de öğreticiler nezdinde kemikleşmiş olan bir dindarlık ölçeği geliştirmiş olması da adı geçen eserin zamanla klâsikleşmesine neden olmuş gibidir. ${ }^{5}$ Bilindiği gibi neredeyse bu yüzyılın ilk çeyreğinde kaleme alınmış olan bu ilmihâle dek elde yeni alfabeyle kaleme alınmış olan pek bir eser de yoktu. Osmanlı harfleriyle basılmış olan ilmihâllerin olması, eski yazıyı bilmeyen toplum için hiçbir anlam ifade etmemekteydi. O yüzden de bu hâle yeni devletin dine ve dinsel olanın görünümüne karşı olan zecrî tutumu da eklenince, dinî konularda uzun yıllar büyük bir cehalet ortamının devem ettiği görülmektedir. Belki de bu halkın geleneksel değerleri din yerine koyarak bulduğu her şeye sarılmasının altında yatan gerçek neden devletin yaşatmış olduğu bu mahrumiyet duygusu olabilir.

İnsanların günlük ibadetlerini ve dinsel yaşantısını kural içerisine alan ilmihâl türü eserler, başka bir açıdan temel bir ihtiyaç olarak da görülmüştür. Bu yüzden de İslâmî ilimler içerisinde günlük hayatın dindarlığına dönük veçhesi en güçlü olan fikhın gelişmesi, genel olarak bu alandaki bilgileri kodlayan ilmihâlin de günlük yaşantıyı kapsamasına neden olmuştur denilebilir. ${ }^{6}$ Diğer bir ifadeyle, Müslüman halkın yeni dinini merak etmesi sonucunda onları bilgilendiren bu tür eserlerin ortaya çıkması da normal karşılanmalıdır. Hatta dinî konuların güçlü bir merakı celbetmesi, bu konularda kısa zaman içerisinde pek çok eserin kaleme alınmasını tazammum ettirmiştir. Hem, sürekli değişen, gelişen ve genişleyen İslâm toplumu içerisinde bu durumun iktizası, kaçınılmaz bir netice olarak da kabul edilebilir. Müslüman halkın diğer kültürlerle karşılaşması neticesinde, inanan ve inanmayan pek çok kişinin aynı toplumda beraberce yaşamaya başlamış olması, büyük ölçüde toplumsal homojenliğin de kaybolmasını gerektirdiği için, zamanla inananların benzer ritüelleri yapmasını öğreten ortak eserlerin yazımına ihtiyaç hâsıl olmuştur.

5 İlgili eserin popüler dindarlık üzerindeki etkisini göstermek için bir iki örnek vermek gerekmektedir. Bunlardan ilki Kur'an'a abdestsiz (gusül hâlinde de aynı yasaklar geçerlidir) tutmanın haram olduğu hükmüdür. Diğer bir deyişle Kur'an'a dokunmak için abdest almanın hükmü "farz”dır. Bkz. Abdurrahman Haçkalı, Muhtasar Íslâm İlmihâli, Bişkek 2008, s. 65). Aynı şekilde: "Abdestsiz bir kimse namaz kılamaz, tavaf edemez, bir mahfaza içinde olmaksızın Kur'an'ı tutamaz, Kur'an'ın tam bir ayetinin veya bir kismının yazll bulunduğu bir levhaya el süremez. Bunlarl yapmak haramdır." (Bkz. Ömer Nasuhi Bilmen, Büyük İslâm İlmihâli, s. 83.) Bu hüküm, bugün itibariyle sıradan dindarlığın yaşandığı her ortamda aşılması çok zor gözüken temel bir kabul hâline getirilmiştir.

${ }^{6}$ Bugünkü şekliyle pek uygunluk arzetmese de ilmihâl türü eserlerin tarihsel süreçlerde görülen ilk şeklinin, özellikle inanç ve ibadetler konusundaki temel esasları/ilkeleri ifade ettiği söylenmektedir. Mamafih bu yüzden de bazı çevrelerce esasında kelâmî bir nitelik taşıyan ve doğrudan fikhın konularını içeren bir eser olmasa bile, İmam Azam Ebû Hanife'nin Fıkhu'lEkber'i, (el-Fıkh'ul-Ekber, İstanbul 1981) bu tür eserlerin ilk örneklerinden kabul edilmiştir. Ancak bazı kişilerce ilmihâl türü eserlerin ilki olarak gösterilen bu eser, teknik anlamda ilmihâl klasiğinde tertip edilmemiştir. Zira mevcut ilmihâllerdeki fikhî detaylar, adı geçen eserde de olduğu veçhile, ilgili eserlerin ilk örneklerinde görülebilen bir durum değildir. Belki de bu yüzdendir ki Müslüman toplumun geleneksel eğitim-öğretim kurumlarında tahsil edilen dindarlığın "öğretim süreci", bahsi geçen eserde de olduğu gibi mutlak surette akîde ile başlamaktadır. 
İlmihâller nezdinde ahlâk denilince, öncelikli olarak nezaket ve görgü kurallarının ifade edildiği görülmektedir. Onun içindir ki bazı ilmihâller, ahlâkî konuları bu çerçevede dar bir eksende ele almışlardır. Hâlbuki bu gibi edep kuralları, kişinin aslî unsur değil, öğrenilmiş bir kazanımı olmalıdır. Ahlâk alanının bu denli sı̆̆ tutulması, ufku kendi mahallesinden dışarı çıkmayan bir Müslüman tipini doğurmuş gibidir. İlgili karakterin kodlandığ olan şeyler de sinırlı olmakta, hatta bazen de gereksiz adımlar olarak görülmektedir. Çevresinde olan her katliam karşısında kişisel ve toplumsal çıkarlar uğruna zulme ses çıkarmayan Müslüman tipi, bu algının sınırlı dünyasından doğmaktadır. Keza, bu algının bütünüyle yabancı olduğu fok katliamına karşı çıkan, denizlerin kirlenmemesi için eylem yapan, kimyasal atıklar için mücadele eden, açlığın kökünün kazınması uğrunda zenginlerin tüketim kalemlerinin azaltılması için bülten hazırlayan vb. atraksiyon sahipleri genellikle Müslüman toplumlardan beklenmemektedir. Dahası ahlâkın yerelliği öteki için riske giren bir Müslüman tipinin oluşumunu da engellemektedir. Öyle ki bütün kutsal metinlerde inanç ve ibadet eylemselliği içerisinde kişisel kazanımlara doğrudan eklemlenmiş bir vasıf olan ahlâk, ilgili eserlerde olmazsa da olur babında işlendiği içindir ki, duyarlılıkları gereği sömürü düzenine karş1 ayaklanmayı başaranlar, Müslümanlar değil, liberal ve sol eğilimi benimsemiş olan bazı kuruluşlar ve NGO'lar olmaktadır. Aynı şekilde Müslüman ülkelerde çevreci bir örgütün olmaması, bu alanların özellikle dinsel alan olarak görülmediği içindir. O yüzden de bu gibi sorunlar karşısında uzun süredir tedris edilen bilgilere dayalı olarak temel kazanımlara dönüşememiş olan Müslümanların ötekine bakışı ve onlarla ilgilenme bilinci, diğer bir deyişle sosyal ahlâk1, sahibi için herhangi bir eylemsellik de öngörmemektedir.

Belki de halk ve öğreticiler nezdinde peşinen kabullenilmiş olan kolaycılık ilkesi, araştırma, sorgulama ve eleştiri külfetine katlanmadan tek hakikatin bu eserlerden geldiği rahatlığını temin etmiştir diye ileri sürülebilir. Bu konudaki en belirgin tanımlama, ülkemiz örnekliğinde daha belirginleşmiş gibidir. Harf devriminden sonra elinde kalan az sayıdaki eserlerden olan ilmihâllerin dini bilgi ve yaşantıyı önemseyen gençlik üzerine kalıcı etkileri olduğu muhakkaktır. Görebildiğimiz kadarıyla bu gibi dönemlerin dindar gençliği, elinde olanla yetinmeyi tercih etmesi, ya da kendisine sunulanı eleştiri süzgecinden geçirmeden doğru olarak görmesi, daha kuralcı bir dindar yapının ortaya çıkmasına neden olmuştur. ${ }^{7}$ Öyle ki bu gençliğin zihinsel algıları, ilmihâl türü eserlerin verdiği bilginin doğası gereği daha kesin durmaktadır. Hatta bunların bir kısmı, ilgili zihinsel yapıyı doğrudan onaylar şekildedir. Çok az bir kısmı ise kendi geleneğine eleştirel bakabilmektedir.

\footnotetext{
7 “Kitapta yazıyorsa doğrudur" şeklinde kurumsallaşmış olan ilgili algıyı eleştirel mahiyette ifade eden eserlerin olmuş olması, yalnızca ilmihâl bilgisinin oluşturduğu dindarlık algısıyla yetişen dindarların olduğu gerçeğinden hareket etmektedir. Nitekim bir dönemin dindarlık algısı üzerinde derin etkiler bırakmış olan bu algının üretmiş olduğu gençlik tipi üzerine edebî eleştiriyi ihtiva eden bazı çalışmalar da vardır. Bu konudaki çalışmalardan birisi olan Mehmet Efe'nin, Mızraksız İlmihâl/Romantik Deneme, İstanbul 1992 adlı eseri, ilgili tasavvuru genel hatlarıyla gözler önüne sermektedir.
} 
Dini bilgilerini daha ziyade ilmihâllerden alan gençliğin, öğrendiği bilginin yapısı ve bireyin gelişim dönemi itibariyle akademik esneklikten uzak, daha kuralcı ve kesinlik arzeden ifadelerle düşünmesi normal karşılanmalıdır. Onun için helâl veya haram vardır. Ara hükümlerin olması, fikirsel esneme, olguyu te'vil etme, kendi dışında da farklı doğruların olabileceği gibi durumlar, onun zihin dünyasına oldukça yabancıdır. Bu yüzdendir $\mathrm{ki}$, bu tasavvur şeklinde geleneksel kaynaklardan öğrenilmiş olan kesin hükümlerde herhangi bir esneme olamaz. $\mathrm{Bu}$ algının beslediği tutuma göre, bir şey ya doğrudur, ya da yanlıştır. Dinsel yaşantısını ilmihâl ve fikıh dindarlığg üzerinde kuran her bireyin din algısı, yapısı itibariyle ötekine karşı yabancı ve sert durur. Kendi dindarlığını besleyen geleneksel kaynaklarında geçen her şey doğru, bilgi veya hakikatin bir yansıması olarak görülür. Hâsılı sadece geçmişte değil, zamanımızda da kalıcı etkileri görülmekte olan bu dindarlık çeşidi, “düşünce üretimi”nden çok “duyum ”üzerine bir dindarlığ 1 önceler. Fikrin sertliği ise, öğrenme süreçlerine müdâhil olduğu kişisel ve toplumsal tabakalarda daha ziyade "fikrin militanı" denilebilecek bir zihniyet üretmesidir.

Görebildiğimiz kadarıyla geleneksel ilmihâl eğitiminin ahlâk umdeleri, ananevî dindarlığın önemsendiği bir yapı olmakla birlikte, yeni ve yaşanan zamanı önceleyen bir yapıya işaret etmekten oldukça uzak gözükmektedir. Hatta bu eserler, ibadetlerin şekilsel yönlerini daha bir önceledikleri için ahlâkî kazanımlara vurgu yapan, kişisel ve de zihinsel özgürlük süreçlerini dikkate almayan bir yapıda kaleme alınmışlardır. Hatta bu eserlerin, ibadet becerisi ve gelişimini tercih eden ve bu beklentileri de öncelikli öğretim materyali yapan eserler oldukları görülmektedir. Bu yüzden de ahlâkî kazanımların daha gerilere atıldığı ve insanlara güzel hayat yaşatan bu kazanımları adeta bir nefsi güzelleştirme malzemesi gibi gören ilgili dindarlık eğitimi, süreç içerisinde bazı problemlerin de kaynağı durumun gelmiş gibidir. Yani şekilsel dindarlığa kayan her türlü ibadetin yapıldığı, ancak bu ibadetlerin kişiye kazandırması gereken ahlâkî kazanımların unutulduğu bir kaba Müslümanlık tipi de gelişmiş bulunmaktadır. Kanaatimizce netice olarak elimizde kalan bu yapının bir müsebbibi de ilgili eserlerin din algısıdır.

Gelinen bu aşamada ifade edebiliriz ki, ilmihâller ahlâkî kazanımlardan bahsetmiyor değildir. Ancak onların ahlâkî kazanım olarak gördükleri şeyler, tâdil-i erkân boyutunda kalmış gibidir. Diğer bir deyişle, herhangi bir ibadetin dışsal şartlarının yeterli olması, onun kabulü için gerekli bir sebep sayılmalıdır. Hatta bu yapının tesis etmiş olduğu inanç ve ibadetin formel sınırlarında kalmayıp, buna mukabil kendi algı çerçevesinde kişisel ve toplumsal gelişimi destekleyici ahlâkî kodlarını da tesis etmiş olması, esasında bu dinselliğin de sıradan halktan belli bir beklentisinin olduğunu göstermektedir. Öyle ki bu klâsik inşânın görünür pek çok sorunu da barındırdığı yadsınamaz bir hakikat olarak karşımızda durmaktadır. Diğer bir deyişle, toplumsal dindarlığın vazgeçilmez eserlerinden olan ilmihâllerin, sadece Müslümanlar nezdinde değil, insanlık ölçeğinde ve herkes tarafından kabul edilebilecek olan kalıcı bir ahlâkî değer/ilke üretememe sorunuyla karşı karşıya olduğu söylenebilir. Denilebilir ki ilgili metinler, geleneksel Müslüman toplumun sosyal, siyasî ve dinî yaşantısında doğrudan bulundukları hâlde, niçin âdil, bütüncül, sağlam ve güçlü dindar karakter üreten bir kişiliğin evrimine destek olamamıştır? Kanaatimizce bu negatif 
gelişimin sıralı nedenlerinin başında, ilmihâl kültürünün "evrenseli" değil, "buradakini” hedeflemiş olması, yani "yerli olması" gelmektedir.

Müslüman bireyin tefekkür boyutu genişledikçe, ötekiyle olan ilgisi de ilerlemiş görünmektedir. Buna uygun olarak Müslümanın ilişki ağına sosyal ahlâkın yerleşmesi akabinde, toplumsal değişimin icrâsı işi daha kolaylıkla sağlanmış görünmektedir. O kadar ki, bu gelişmelerin şansı, bütünüyle bu kazanımların ahlâk formu içerisinde kabul edilmesine bağlıdır. ${ }^{8}$ İnsanî olan her çağriya kulak veren ahlâklı Müslüman tipi, ahlâkî değerleri yaşam tarzı hâline getirmiş olan kişiliklerin inşasıyla olacaktır. Müslümanın muhafazakârlaşmasını temin eden ilmihâl dindarlığı, tabiidir ki devrimci bir karakterde olan nebevî algıyı da tarihsel olgusallığın ötesinde anlayamayacaktır. Onun için zalim, kâfir, müşrik ve nifak düzenine başkaldıran elçiler, sadece tarihsel birer aktör mesabesindeki örneklemlerdir. Mamafih benzer nedenler baş gösterdiğinde Müslüman bireyin de onlar gibi davranması gerektiği bilinci, bu yapıdan biraz zor çıkar gözükmektedir. $\mathrm{Bu}$ sonucu tahsil eden durumu ileri sürmemizin asıl gerekçesi, yüzyıllardır itaat kültürünü dinsel bir kazanım olarak sunan ilmihâllerin varlığıdır. Zira cihat ve mücadele ahlâkının işlendiği ilmihâller, bir elin parmaklarını geçemez. Olanlar da savaş hukukundan öte bir açıklamayı geçememiştir. Nitekim "isyan ahlâkı"nın" kodlandığı bir ilmihâl yazılmadan, Müslümanların tarihte özne konumuna gelmeleri mümkün değildir. Zulüm ve otorite karşısında inanan insanı tarihin adeta nesnesi durumuna getirmiş olan ilmihâller, içerik değeri açısından da Müslümanın kıyam hâlini değil, sukût hâlini önermektedir. Hâlbuki kutlu elçiden eğitimini aldığ ilkesinden hareket eden herkes, ${ }^{10}$ "emr-i bi'l-mârufnehy-i ani'lmünker"in tebliğ faaliyetinde öncelikli adım olmasını öğrenmiş olmalıdır. Hatta bu görevi destekleyen Kur'an-1 Kerim, Asr Suresi’nin kendisine verdiği yetkiyi kullanan herkes için siyasî, sosyal, ekonomik ve dinî bir projesinin olmasını da öngörmektedir.

Netice olarak diyebiliriz ki, ilmihâllerin genel geçer yapısı olarak görülen " $k a t ı$ kuralcılık" hususu, dinî yaşantının işlevsel olduğu her ortamda ister istemez bir "öteki" yaratmış durumdadır. Yaratılan bu öteki, öncelikli olarak dinsel yahut toplumsal tabakalardaki karşıt algı sahiplerini ifade etmektedir. Ona göre ötekiler, ortak dinsel değeri paylaşmayan kâfir, müşrik ve münafiklar olduğu kadar, diğer mezhep müntesipleri olarak da görülmelidir. Zira 'bizim mezhebimize göre' lafz1,

\footnotetext{
${ }^{8} \mathrm{Bu}$ konuda destekleyici mahiyette bazı hadis rivayetlerinden bahsedilebilir. Mesela, güzel ahlâkın yerleşmesi/yerleştirilmesi için seçilmiş örneklikler üzerinden davranış kazanımına dönüşebileceğini ifade eden şu rivayet, bu konuda diğer elçilerde olduğu gibi, Resulullah'ın örnekliğini de açıkça göz önüne sermektedir: "Ben, güzel ahlâkı tamamlamak için gönderildim!" (Bkz. İmam Mâlik b. Enes, Muvatta, Hüsnü'l-Hulk, 8). Ayrıca, güzel ahlâkın halk için görünür bir değer olduğunu ifade eden şu rivayet de, güzel ahlâkın esas amacının öncelikli olarak halkın eğitimi üzerinden somut kazanımlara ulaşmak olduğuna işaret etmektedir: "Muaz b. Cebel (Yemen'e vali olarak giderken): Ayağımı üzengiye koyduğum zaman Resulullah (sav)'ın bana son tavsiyesi şu oldu: Ey Muaz b. Cebel! Ínsanlar için ahlâkını güzelleştir.” Bkz. İmam Mâlik, Muvatta, Hüsnü'l-Hulk, 1.

${ }^{9} \mathrm{Bu}$ betimleme Nurettin Topçu’ya aittir. Bkz. Nurettin Topçu, İsyan Ahlâkı, İstanbul 2006.

${ }^{10} \mathrm{Bu}$ söz, hadis değil, insanlığın mâşeri vicdanında onaylanmış olan bir kelâm-1 kibar' dır.
} 
aynı zamanda 'bizim din anlayışımıza göre' anlamına gelmekte ve bu düşünceyi paylaşmayan büyük bir kitleyi de dışarıda bırakmaktadır. Kabul edilmiş olan ilmihâle göre ortak dinî ve kültürel değerleri paylaşmayanlar, öteki vasfını hak eden gruplar mesabesindedir. Bu kabulün ahlâkî donanımı ise adeta "içimizdeki yabancllar" şeklinde tezâhür etmektedir. Mamafih mensubiyet değeri üzerinde kaleme alınmış olan ilmihâlin öngörmüş olduğu ortak akidevî, ibadî ve toplumsal amacı paylaşmayanlar, gerek dinî açıdan, gerekse de ahlâkî açıdan eksik unsurlarla bezenmiş olarak kabul edilmektedir. Ana bünyenin dışında kalanları tanımlamakta olan "bizden olan muhalifler" ve "diğerleri" algısı, esas olarak ötekileştirme üzerine tesis edilmiş olan dışlayıcı bir ahlâk modelini de tazammum etmektedir denilebilir. Mikro ölçekli düşünen bu yapıdan da ümmet fikrinin çıkması mümkün görünmemektedir. $O$ yüzdendir ki Müslüman toplumlarda herhangi bir şey üzerinde olduğunu ileri süren herkes, elinde bulduğu şeyle övünmektedir.

Sözün özü, toplumsal merkezin teşekkülünde oldukça etkin olan eserlerin başında gelen ilmihâllerin yerleştirmiş olduğu "ahlâk algısı"nın öğrenilmesi, ilgili eserlerin "din algisı" üzerinden tesis edilmiş olan toplumu daha yakından tanımamıza imkân verecektir. Öyle ki Kur'an'ın neredeyse bütününde inanç ve ibadet formlarına giydirilmiş olan ahlâk ölçüleri ve dahi kazanımları, yaşamakta olduğu hayatın içerisinde sınanmakta olan birey için, beşerî kazanımın önemli unsuru olarak görülmesi gerekirken, ${ }^{11}$ ilmihâllerin tesis etmiş olduğu din anlayışında adeta sayısal verilere dönüşmüştür. Zira ilgili eserlerde yapılacak olan eylemselliğin akla gelen ilk kazanımı 'şu kadar sevap' ya da 'şu kadar günâh' seçeneği üzerinden dile getirildiği için, ibadetlerin yapılış amacı da bir nevi somut çıkar odaklı bir faaliyet alanına indirgenmiş olmaktadır. Bu yüzdendir ki ilmihâlahlâk ilişkisinin kodladığı klâsik bireysel yapı, ötekilere sunulacak bir projesi olması gereken biz Müslümanların temel dertlerinden birisi olmalıdır. Tebliğ vazifesini uhdesine almış olan her kişinin böyle bir endişe taşıması da eşyanın tabiatına uygundur. Hatta bu endişenin paralelinde gelişen bir anlayışla insanlara yaklaşmak ve onlara dâvetteki ölçüyü hatırlatmak gerekmektedir. Mamafih insanın ahlâkî kazanımını önceleyen her adım gibi bu alan da, geleneksel insan yetiştirme düzenimizin sorunlu bir alanı olarak da karşımızda durmaktadır.

\section{2-Problemin İçeriği}

Geleneksel din algısı, ibadetin süreklilik arzeden kazanımları üzerinden değil, şeklî bütünlük anlayışı üzerinden bir ibadet hayatı öngörmektedir. O nedenledir ki

\footnotetext{
11 Ahlâkî değerlerin hayatın bütünü içerisinde aranması gerektiği fikrinin Müslüman muhayyilesinde güçlü bir karşılığ̣ yok gibidir. Bunu içindir ki ilgili toplumsal yapıda ahlâk olarak kabul edilmiş olan şeyler, genellikle iman ve ibadet alanının dışına taşırılmış gibidir. Oysaki inandığı kutsal değerlerin kişiyi daha ahlâklı yapacağı fikri, esasında nebevî örneklik olarak önümüzde durmaktadır. Zira Hz. Ayşe validemize Hz. Peygamberin ahlâkı sorulunca o: "Siz, Kur'an okumuyor musunuz? Onun ahlakı Kur'an idi" şeklinde cevap vermiştir. (Bkz. Müslim, Musâfirîn, 18). Aynı şekilde Hz. Peygamberin fiilî ahlâkı "yüce bir ahlâk üzerinde olma" (Kalem, 68/4) ve "güzel bir örnek" (Ahzâb, 33/21) şeklinde Kur'an'ın iltifatına da mazhar olmuştur. Bilindiği gibi Allah Resulü, kendi misyonunun "güzel ahlâkı tamamlamak" (Ahmed b. Hanbel, Müsned, II, 281; İmam Mâlik b. Enes, Muvatta, Hüsnü'l-Hulk, 1) olduğunun farkında olarak insanlarla iletişim kurmaktayd.
} 
ibadet hayatını düzenleyen kuralların sayısı, neredeyse ibadetin hatasız bir şekilde icrâsını imkânsız hâle getirmektedir. Oysaki ibadetler, takvaya ulaşımın aracı mesabesinde olan ve bu sayede beşerin tevhîdî bütünlüğü yakalayabilecek bir bilincin kazanımı konusundaki yardımcıları olarak görülmelidir. Hem geleneksel algıda olduğu şekliyle, ibadetin bir süreklilik hâli olduğunu kabul etmeyen bir din anlayışının bütünüyle ahlâkî kazanımı ön plana alması da söz konusu olamaz. Mamafih ifade edildiği üzere, pek çok zaafla çevrelenmiş olan insanı daha iyi bir insan yapabilecek olan ibadeti, behemehâl ödenecek bir borç olarak gören ilmihâl zihniyetinden, ibadetin ahlâkî kazanımlarını gören bir anlayışın çıkmayacağı, hatta çıkmadığı da açıkça söylenebilir. Bu bilincin tahsili için ise, öncelikli olarak tekbir alma ve namaz kılma şekillerinde olduğu gibi, formel zenginliğe vurgu yapan bir anlayışın Hz. Peygamberin de bilinçli olarak yaptığı tarzda bazı şekilsel sınırlamalardan kurtulması lazımdır. Böylelikle şeklî dindarlığın baskısından kurtulan herkes, mutlak olarak ibadetin amacını daha kolay kavrayacak gibidir. Ancak bu demek değildir ki, ibadetlerdeki şekil unsurlarının tamamı gereksizdir. Demek istediğimiz şey, nebevî örneklerde de gösterildiği üzere şeklin özün yerine geçmemesidir.

İlmihâllerin bazılarında Peygamberler tarihi ve siyerle ilgili olarak verilen bilgiler, peygamberlerin ahlâkıyla ahlâklanmaktan çok, tarihsel bilgi aktarımı ve hikâye/kıssa şeklinde dile getirilmiştir. Bugün yaşanmakta olan durumlara örnek olabilecek çözümlerin peygamberlerin yaşam öykülerinde olabileceği fikri, ilgili metinlerin temel eğilimi değildir. O nedenledir ki adı geçen anlatımlarda elçilerin başvurdukları çözüm şekillerinin örneklik vasfı üzerinden güne taşınabilirliği değil, karşılaşılan sorunların aktarımı esas alınmış gibidir. Peygamberlerin örnekliği konusunda amaç üzerinden ortak bir dil geliştirememiş olan bu yapıda, kıssa ve tahkiye dilini geçemeyen nebevî hayat hikâyelerine de yer verilmektedir. Öne çıkarılan gizemli değerlerin yedeğinde bir anlatının görüldüğü bu bölümlerde, tarihte yaşamış bir kişiliğin hayatı romansı bir eda ile anlatılmakta olduğundan bundan maada bir fayda da beklenilmemelidir. İfade edilebilir ki kendi çağını yaşayan kişiler için "yaşayan örneklik" statüsü anlamındaki bu değiniler, ilgili bölümün araçsal bir hedefi hâline gelememiştir. Mesela hiçbir ilmihâlde, Hz. Musa ve Hızır denilen şahıs öyküsünde dile getirilmiş olan esas değerin, Hz. Musa'nın tavrı olduğu vurgulanmaz. Hatta gizemli yaşantıyı merkeze almış olan tasavvuf doktrinlerinde bu anlatı üzerinden tevârüs edilen ve Peygamberlerin bile ulaşamadığı farklı ilimlerin olduğuna işaret edilmektedir. İlgili anlatıda kıssanın amacına ters düşmek pahasına "ilm-i ledün" diye bir ilmin olduğu, bunun da bazı kişilerce tahsil edilebildiği vurgulanır. ${ }^{12}$ Hâlbuki bizler için tahkiye edilmiş olan nebevî öykülerde aslolan şey, peygamberlerin davranışlarının

\footnotetext{
${ }^{12}$ H. Hilmi Işık, Tam İlmihâl/Seadeti Ebediyye, İstanbul 2009. Eserde tasavvufun bütün kabulleri, rabıta, levlâke gibi tevhide bütünüyle aykırı olduğunu düşündüğümüz inanışlar bile hâlâ temel bir gerçeklik öğretisi üzerinden açıklanmıştır. ( Bkz. Işık, age, ss.33, 450, 920-921, 955). Keramet konusunun bazı ilmihâllerde inanç esası gibi takdim edilmiş olması, keramet gösteren velînin, esasında bağlı olduğu peygamberin haklılığı için bir delil olması hasebiyledir. Bkz. Ali Tantavi, Íslâm Dini, İstanbul 2000, ss. 344-347. Ayrıca ölüleri takdis etmenin sebeplerini işleyen ilmihâller de bulunmaktadır. Bkz. Tantavi, age, s. 270.
} 
örnekliğidir. Zira bu öykülerde insanoğlu için bağlayıcı olan başkaca bir örneklik üzerinde de durulmaz.

Dahası, mevcut ilmihâl ahlâkının düşünsel boyutu, şekilci yapıdan kurtulup, özsel bir yap1 üzerinde tesis edilmelidir. İndirgemenin olası vasfı bu minvâl üzere olursa, İslâm ve iman anlatılırken başvurulan 5 ve 6 şart gibi temel şart mantığı da aşılmış olacaktır. İşte o zaman temel esasların zaman ve zemine göre öncelenebildiği ve de sonsuz olabildiği güçlü, duyarlı ve etkin bir dindarlık ölçeği de geliştirilmiş olacaktır. Hâsılı kelâm, İslâm'ın hedeflemiş olduğu kişi ve toplum kurgusuna uygun bir dindarlık ölçeği, geleneksel ve daraltıcı kabullerin üzerinden değil, amaç ve hedeflerin üzerinden gidilerek tahsil edilebilir. O nedenledir ki bu algıyla paralellik arzetmesi için, öncelikli olarak sorumluluk sahibi bireyler üreten yeni bir ilmihâl ahlâkı/kültürü geliştirilmelidir.

Klâsik algının beslediği ilmihâl yazım geleneği, öncelikli olarak fikıh dindarlığı üzerinden işlevsel olduğu için, ötekinin derdiyle hemdem olan ve küresel sorumluluk ahlâkı üzerinden dünyaya öğretilebilecek yeni bir dindarlık türü gelişememiştir. Bu yüzdendir ki ilmihâller, toplumların içerisinde bulunduğu duruma cevap teşkil etmemekte, sömürü, işgal ve tasallutlara karşı kişi ve toplumları koruyup kollayacak tedbirler üzerinde duramamaktadır. ${ }^{13}$ Nitekim mazlum halkların yaşadığ 1 yerler, askerî bakımdan güçlü tiranlar tarafindan işgal edilip oluk oluk kan akarken, ilmihâllerin temel konuları arasında hâlâ tâdil-i erkân ya da kerâhet vaktinin tespiti olabilmektedir. Yani, dişarıda yaşanan dünyanın sorunları ilmihâlin konuları içerisine bir türlü girememektedir. Kanaatimizce ötekinin derdine karşı güçlü bir duyarsızlık hâli geliştiren bu eğilim, -ilmihâllerin doğrudan etkilemesi sebebiyle -sıradan halkın dindarlık ölçeğinin fikıh ile sınırlı olmasını tazammum ettirdiği için, diğer bir deyişle ahlâkî kazanımların ikinci plana atılmış olması hasebiyle, hak dinlerin yerleştirmeye çalıştığı merkez duygulardan olan "ötekine karşı sorumluluk duygusu"nun oluşumunu da engellemektedir.

Oysa inanç ve ibadetlerin amaç olarak görüldüğü klâsik dindarlık biçimlerinde, görev olarak telakki edilen her değerin ifası neticesinde, kişisel yükümlülükler sona ermekte, ilgili fiilin kazanımı üzerinden kendine ve ötekine karşı bir sorumluluk duygusu gelişememektedir. Hâlbuki sahici bir dindarlıkta inanç ve ibadetlerin kuralına uygun bir şeklide ifâsı asıl amaç değil, ilgili eylemsellik üzerinden gerçekleşecek olan hâsılanın kalıcı olması durumu gerçek hedef olmalıdır. O yüzdendir ki inanan ve ibadetini eksiksiz yerine getiren her insan, görevini yerine getirmiş olmanın bilinciyle kendi çıkarı için tabiatı tahrip etmekte, tüketemeyeceği şeyi satın almakta, yiyemeyeceği şeyi biriktirmekte, kendisine bir saldırı olmadığı müddetçe devletinin menfaatini, ümmetin menfaatine tercih etmekte, mazlumun yanında durman faturasını göğ̈̈slememekte hatta zalimlerle

\footnotetext{
${ }^{13}$ Bazı ilmihâllerde hâlâ “daru'l-harp hukuku” işlenmektedir. Bkz. Sıdkı Gülle, Ehl-i Sünnet ve’lCemaâta Göre İslâm Akaidi ve Hanefi Fıkhına Göre İslâm İlmihâli, İstanbul 1987. Hatta Müslümanların yaşadığı ortamlar bu fikha göre tanzim edilmekte, dolayısıyla bazı yükümlülükler düşmektedir. Gülle, age, s. 658. Ancak aynı ilmihâlde klâsikleşmiş konuların "Kıyâmet alametleri", (s. 112-122) işlendiği kadar, oldukça modern sayılabilecek konular "doğum kontrolü”, (s. 659), "evlat edinme”, (s. 660), "balayı", (s. 662) da ele alınmıştır.
} 
ekonomik ve sosyal ilişkiler geliştirmektedir. Klâsik dindarlığın şekilsel kazanımları üzerinden tesis edilmiş olan bir Müslümanlıktan da bundan başkası beklenemez.

Zamanının büyük bir kısmını takva beklentisi üzerinden sadece şeklî ibadet ve sözlü zikirlerle geçiren bir müslümanın, ibadet denilince anladığı şeyleri yeniden sorgulaması gerekmektedir. $\mathrm{O}$ yüzden de günümüz müslümanının ibadet denince artık yanıbaşındaki akan kanın durması için çalışmayı, bedenini pazarlayan insanlarla ilgili derdi olmayı, bağımlılık yapan maddelerden olan kumar, sigara, alkol, esrar, eroin vb. gibi yıkıcı alışkanlıklarla mücadele etmeyi dindarlık portföyüne eklemesi gerekmektedir. Artık kalıcı Müslümanlıklar için söylem düzeyi dışında yeni şeylerin husûle getirilmesi, yeni ortaklıkların yapılması gerekmektedir. Dahası, Müslüman algının sadece ümmetin değil, insanlığın sorunlarıyla ilgilenirken ilmihâllerin yüklemiş olduğu "yeterlilik" duygusundan sıyrılması gerekmektedir. Zira toplumsal sorumluluğu pekiştiren ifadelerin başında gelen ve "size ne oluyor ki..."14 diye başlayan ilâhî hitapların mutlak surette bir anlamı olsa gerek.

Denilebilir ki hâlihazır ilmihal kültürü, oluşturduğu dindarlığın yapısı gereği olası sınırları daraltılmış ve keskin dinî yapısı gereği de değişmez ve esnemez bir dinsel karakterin kaynağı gibi durmaktadır. Bunun içindir ki bu algıyla yetişmiş olan Müslümanlar nezdinde ötekini anlamak, onun uygulamalarını benimseyebilmek, başa çıkamadığı durumlarda oradan delil getirebilmek gibi değişim değerleri bütünüyle imkânsız olmaktadır. Mamafih ilmihâl ahlâkının yetiştirdiği bireyin dünyasında yabancı unsur hükmünde olan her bilgi, ötekinin reddi için yeterli ve gerekli bir bilinç düzeyini oluşturmuş gibidir. Onun için tutarlı ve etkin bir din algısının beslendiği her obje, ilkesel yakınlık üzerinden kurgulanmayıp, aidiyetleri üzerinden işlevsel olabilmektedir. Dahası, ilgili Müslümanlığın düşünce modelinde öne çıkan şey, sadece bizden olanın doğru ve geçerli olduğu algısıdır. $\mathrm{Bu}$ algının doğrudan ürünü olan her eylem de, ancak mevzî bir kazanımı onaylayan normatif ve daraltıcı bir dinî yapıda gerçekleşmektedir.

Akabinde ise ilmihâlleri kutsal ve hakikati ifade eden metinler olarak gören sıradan halkın, kendisine sunulan bilginin ilmihâl yazarının mezhep ve meşrebini aşamayacağı seçeneği ise büsbütün göz ardı edilmektedir. Bu ayırımı yapamayan sıradan halk için ilmihâl, mutlak manada doğru bilginin taşındığı eserler hükmündedir. Bu yüzden de ilgili kişiler, ilmihâller üzerinden kendisine sunulmuş olan bilgileri doğrulanmış ve kesinlik arzeden dinî bilgi olarak kabul eder. Hatta: "kitapta yeri var", "sen onlardan daha iyi mi bileceksin?", "koskoca ilmihâl yazarl yanlış söyler mi?"... diyerek, kişisel kabullerinin tasdikinde delil olarak da göstermektedir. Bilindiği gibi gerek öğreticiler nezdinde, gerekse de öğreniciler nezdinde bu geleneğin en çok bilinen delillendirme formu olarak "şurada yazılıdır" ifadesi kullanılmaktadır. Hem bu ifadenin sıradan bir anlamı da yoktur. Zira kişiler, bu ifade üzerinden Müslümanlıklarını sağlama almış olmanın yanında, aynı zamanda hakikat ifade eden bir esere de atıf yapmış olmaktadırlar.

\footnotetext{
${ }^{14}$ Nisâ, 4/75, Tevbe, 9/38, Hadîd, 57/10.
} 
Hâs1l-1 kelâm olarak ifade edebiliriz ki, herhangi bir mezhep ya da meşrebin bak1ş açısıyla kaleme alınmış olan ilmihâllerin, içe dönük bilgilendirme yapan vasfı gereği, çevresindeki olaylara duyarsız kalmaması gereken insan ve toplumu kısıtlayan, hatta sınırlandıran bir yapısı daha vardır. Bu sınırlı algı, Müslüman kardeşini tercih etmiş olduğu eylemsellik üzerinden diğeri mesabesine indirgemeyi haklı görmektedir. Mamafih hacca gidip gelen Müslümanların cehaletleri üzerinden diğer müslümanların İslâmlığını beğenmeyen ifadeleri kullanmaları sıkça görülen şeylerdendir. Bu hâkir görüş, sahibi için evrensel İslâm algısını daraltıcı bir etki de yaptığı için, kardeşlik ahlâkına negatif bir katkı da sunmaktadır. Hatta bu sinırlı din algısı, Müslüman toplumların üretkenliğini de öldürmektedir. Halkın dindarlığını besleyen hocalar ise, yeni bir durum karşısında bütün sözleri incelemek yerine bu tür eserlerden nakil yapmayı tercih etmişlerdir. Bu sayede geleneksel halk dindarlığının görüldüğü her katmanda ezber konumuna gelmiş olan bu tür eserler, mevcut durumda olduğu veçhile, sadece hakikatin yegâne ölçüsü hükmünde algılanmamakta, çeşitli soru ve sorunlara karşı verilecek olan cevapların ezberlendiği bir tebliğ sürecini de tazammum etmektedir.

Çalışma boyunca ulaşabildiğimiz ilmihâllerin toplam olarak 50-60 bin sayfaya yaklaştığı söylenebilir. Ancak bu kadar sayfa sayısının içerisinde ahlâk konularının oranı ise çok düşük bir yekûn tutmaktadır. Aşağıda sayısal verilerin oranlanmış olduğu tabloda da görüldügü üzere, ilmihâl ve ahlâk ilişkisi, düşük bir iletişim baremi üzerinden sağlanmaktadır. Bu yüzden de halkın genelinin nezdinde önemsiz bir unsur olarak görülmektedir. İnanç ve ibadet konularının neredeyse beşte dördünü kapsadığı bir ilmihâl klâsiğinde, ahlâk ve ahlâkın kazanımları üzerinden işlevsel olabilecek bir dindarlık ölçeğinin de gelişmesi mümkün görünmemektedir. Dahası, mevcut ilmihâllerde ahlâk konuları sanki inanç ve ibadet alanlarından bağımsız şeylermiş gibi verilmekte, hatta inanç ve ibadetin mahsulü olması gereken ahlâkî kazanımların ise bu alanla ilişkisi doğrudan kurulmamaktadır. Bu yapının doğurduğu olası sonuç üzerinden ifade edecek olursak, inanç ve ibadetin temelde bir ödev gayesiyle yapıldığını söyleyebiliriz.

Okuyucu algısı olarak ifade edilebilir ki, sırada insanlar, eserlerin iç düzeninde yer almakta olan konuları önem sırasına göre algılama eğilimindedirler. Onun içindir ki okuyucu nezdinde genel olarak kitapların baş ve orta bölümlerindeki konular daha dikkatle incelenir, sonlardaki konulara ise eserin içyapısı ve okuyucu algısı gereği diğer konular kadar önem verilmez. Mamafih kitabın son bölümüne sıkıştırılmış olan bir konu yapısı gereği üstünkörü bir şekilde incelenir, adeta ana yemeğin üstündeki tatlı mesabesinde algılanır. Eğitim-öğretim işini yapanların bu konuyu daha iyi bildiğini varsayarsak, okullarda ders kitaplarının son kısımlarının genellikle işlenmediği tecrübeler üzerinden kolaylıkla ileri sürülebilir. Hatta ders kitaplarının hazırlanmasında ve ünitelerin yerleştirilmesinde böyle bir temel ayırımdan hareket edildiği de söylenebilir. Zira kitabın sonundaki konular, gerek ilginin toparlanmasına dayalı olarak, gerekse de başka sebeplerden dolayı okuyucuya daha önemsiz gelmekte, bunu için de üstünkörü bir okumaya tabi tutulmakta, hatta ilk konular kadar önem verilmemektedir. Hâlbuki herhangi bir kitap dizaynına esas olarak giriş, gelişme ve sonuç bağlamı üzerinden bakılacak olursa, bu algını temelinden yanlış olması gerekirken, maalesef ilmihâl dizaynındaki görünür hâl de bu durumu destekler mahiyettedir. Üstelik ilmihâl 
eşittir iman, ibadet ve fikhî meseleler anlayışı güçlü bir kabule mazhar olduğundan dolayı, ilgili eserlerde ahlâk ilkeleri genel olarak köşe bucakta durmakta, ${ }^{15}$ bu yüzden de ilmihâllerin giriş bölümlerinde ahlâk konularına ağırlıklı olarak yer verilememektedir.

Hâsıl-1 kelâm olarak ifade edebiliriz ki bazı ilmihâller, bütün enerjilerini Müslüman toplum nezdinde oldukça tartışmalı olan fikhî konulara hasretmişlerdir. $\mathrm{Bu}$ eğilimin sebebi olarak mezhebi taassub ileri sürülebilirse de, bir o kadar farklı dünya görüşlerinin olduğu da söylenebilir. Örnek olarak verilirse bu tür ilmihâllerin ele almış olduğu konulardan bazıları: "Sırat köprüsü", "şefaat", "kabir azabı", "keramet", "selefin kutsanması", "kıyâmet alametleri”, "Hz. Peygamber'in kudsiyeti", "âlemlerinyaratılışının sebebi olan levlake mantığı", "fenâfillah",

${ }^{15}$ Görebildiğimiz kadarıyla bazı ilmihâllerde esas olarak ahlâk konusu temel bir bölüm olmasına rağmen, ilgili konular, kitabın tertip niteliği dolayısıyla ya küçük bir bölümde ele alınmış ya da eserin sonuna doğru yer verilmiştir. Görebildiğimiz kadarıyla ilgili dizayn içerisinde bile olsa yine de ahlâk konusunun işlendiği ilmihâller, genel olarak \%40'a tekabül etmektedir denilebilir. Ancak eserlerin içerisinde işlenen konuların ağırlığı olarak bu oran \%5'lere karşılık gelmektedir. Bu durumun çeşitli sebepleri varsa da kanaatimizce asıl sebep, popüler Müslümanlık ölçeklerinde ahlâkî kazanımların şekil unsurlarına kurban edilmesi gelmektedir. Diğer bir ifade ile ahlâkî konular, şekil şartlarına dayalı olarak gelişen Müslümanlıklarda önemsiz bir ayrıntı olarak durmaktadır. Hatta ilgili tasavvur nezdinde, şeklî unsurları yerine getirilerek tam manasıyla yapılan ibadetlerin yanında daha da önemsiz duran bir ahlâk unsurundan bahsedilebilir. Zira ilmihâl Müslümanlığı nezdinde, öncelikli olarak ibadetlerin şekil şartları üzerinde yerine getirilmesi hususu, mecburî olarak ahlâkî kazanımları da tazammum edeceğine olan güçlü irade bulunmaktadır. Denilebilir ki bu algı, bu çeşit eserlerin kaleme alınmasında baskın bir irade eğilimi olarak durmakta gibidir. Gelinen bu noktada ifade edilebilir ki bazı ilmihâllerde ahlâk konuları yine de 1srarlı bir şekilde ele alınmıştır. Görünür bütün kusurlarına rağmen ahlâk konularının bu minvâl üzere olsa da mutlak surette işlenmiş olduğu ilmihâl türü eserleri şu şekilde siralayabiliriz: Bkz. Burdurlu Mehmed Hatiboğlu, Ana Kaynaklara Göre İslâm Dini/Usulu ve Tatbikatı, İstanbul 1946; İskilipli M. Âtıf Hoca, Yeni İlmihâl, İstanbul 1991; Ömer Nasuhi Bilmen, Büyük İslâm İlmihâli, İstanbul 1957; Ahmed Hamdi Akseki, Askere Din Kitabl, Ankara 1982; Íslâm Dini, Ankara 1982; Din Dersleri, İstanbul 1970; Yavrularımıza Din Dersleri, İstanbul 1947; M. Sabri Sözeri, Mehmetçiğe Din Dersleri, İstanbul 1965; M. Âsım Köksal, İslâm İlmihâli, İstanbul 1977; Hüseyin Algül, Dini ilgiler/İslâm İlmihâli, Ankara 1992; Hüseyin Algül vd., Íslâm İlmihâli, İstanbul 1998; Necip Fazıl K1sakürek, Iman ve İslâm Atlast, İstanbul 1981; Abdülmecid Ünlükul, D̂̂ Mezhebi Ilmihâl, Konya 1962; Hüseyin Atay, Kur'an'a Göre İslâmın Temel Kuralları, Ankara 1985; M. Hayri Kırbaşoğlu, Ahir Zaman Illmihali, Ankara 2011; Süleyman Ateş, Yeni İslâm İlmihâli, Ankara 1979; Mizraklı İlmihal, İstanbul ts.; Murat Elald1, Çocuklar ve Gençler İçin Hayat Rehberi, İstanbul 2010; Çocuklar Iç̧in Din ve Hayat, İstanbul 2007; M. Kemal Pilavoğlu, Müslüman Çocuğun Din Kitabı, Ankara 1964; Ali Kemal Belviranl, İslâm Prensipleri, Konya 1962; Murat Kaya, Ebedi Yol Haritası İslâm, İstanbul ts.; Hacı Reşid Paşa, DîniMübîni'lİslâm, İstanbul 1958; Mehmet Soymen, Cep İlmihâli, Ankara 1979; M. Cemal Sofuoğlu, İslâm Dini Esasları, İzmir 1999; Mehmet Aydın, İslâm Dîni İlmihâli, İstanbul 1984; Abdullah Aydın, Tam İzâhlı Büyük İslâm İlmihâli, İstanbul ts.; Bekir Sitk1 Karaduman, Hülâsâtu'l-Kur'an ve Hülâsâtu'l-İslâm, Ankara 2006; Lütfi Şentürk-Seyfettin Yazıc1, İslâm İlmihâli, Ankara 2009; Ömer Öngüt, Kalplerin Anahtarı İslâm İlmihâli, İstanbul 2004; Beşir İslamoğlu, Modern İlmihal, Ankara 2002; Temel İslâm Bilgileri/Ahlâkım, Ankara 2007; Kemal Güran, Müslümanın El Kitabı, İstanbul 2011; Ali Küçüker, İslâmî Hikmet ve Öğütler, Ankara 2008; Talip Uluşan, Kaynaklara Dayalı Illmihâl, Ankara 2004; Nihat Temel, Kur'an Aydınlı̆̆ında Müslümana Yol Haritası, İstanbul 2006; Hasan Yavaş, Rehber İlmihâl, İstanbul 2009; Abdulaziz Hatip, Gençler Iç̧in İmân ve Ahlâk Rehberi, İstanbul 2005; Mehmet Soymen, Dinî Bilgiler, Ankara ts.; 
"velî", "vahdet-i vücut", "evlilik", "şahitlik", “dâru'l-harb”, "ruhların bedenlerden önce yaratılışı", "ilk yaratılan ruhun Hz. Muhammed'in ruhu olduğu inancı", "klâsik kader anlayışı"...gibi konulardır. Müslüman toplum nezdinde bu denli tartışmalı konuların ilmihâllerde açıkça işlenmiş olması, ${ }^{16}$ eserin güvenliğini sorgulamayan okuyucu bu değinilerin dinin aslından olduğu inancına yöneltmektedir. ${ }^{17}$ Eserin sahibinin mezhep ve meşrebini bilemeyen okuyucu için ise bu tip yorumlar, geçmişte yapıldı̆̆ taşırılarak dindarlığın aslî unsuru olarak kabul edilmiştir. Kitapta yazılanın doğru olduğu bir anlayıştan, kitapta yazılanı eleștirebilen bir tasavvurun çıkması da zor gözükmektedir. Onun içindir ki ilmihâller üzerinde kurgulanmış olan popüler

${ }^{16}$ Ali Küçüker, İslâmî Hikmet ve Ö̆g̈ütler, Ankara 2008; Hüseyin Hilmi Iş1k, Tam İlmihâl/Seadet-i Ebediyye, İstanbul 2009; S. Ahmed Arvasi, İlm-i Hâl, İstanbul 1990; Mevlanâ Muhammed Ali, İslâm Dini, İstanbul 2007; Mızraklı İlmihâl, İstanbul ts.; Mehmet Keskin, İslâm İlmihâli, İstanbul 2006; Abdullah Aydın, Tam İzâhlı Büyük İslâm İlmihâli, İstanbul ts.; Hamdi Döndüren, Delilleriyle İslâm İlmihâli, İstanbul 1991; İsmail Kaya, İslâm Dini ve İlmihâli, İstanbul 1992.

17 İlmihâller, geleneksel ve popüler din anlayışının kabul edilmiş değerleri üzerinde yorum yapmaktan uzak bir anlatımı tercih etmişlerdir. Bu yüzden de ilmihâllerde işlenmiş olan "kader" ve " $k a z a$ " konusu, bütünüyle insanın iradeli seçimlerini dışarıda bırakan bir Tanrı anlayışı üzerinde tesis edilmiștir. (Bkz. Kurt, age, s. 115).Genel olarak Yüce Allah'ın ilim, kudret ve irade sıfatları üzerinde dile getirilmiş olan kader algısı, nihayetinde Allah'ın ilmi ve kudreti etrafında tanımlanan bir olguya dönüşmüştür. Yüce Allah'ın bilgisinin sonsuzluğu ve kudretinin kuşatıcılığı üzerinde yükselen bir kader algısında, söz konusu insanın sorumluluğu olunca ilâhî iradenin kendisini geri çektiğini kabul etmeyen ilmihâl dindarlığı, olanda hayır olduğu düşüncesine iman edilmesini teklif etmekte gibidir. İnsanoğlu, ezelde kader ve kısmetinde ne yazılmışsa ondan öte bir şeye sahip olamaz. Eğer herhangi bir şey, Yüce Allah yazmamışsa dünya ayağa kalksa elde edilemez. Buna karşılık olarak, yine herhangi bir şeyi Yüce Allah ezelde takdir etmişse/yazmışsa, dünya ayağa kalksa ona mani olamaz algısı, insanın iradeli tercihlerine daha başından ipotek koymaktadır. Böyle bir Tanrı-inan ilişkisi üzerinde kurulmuş olan ilmihâl kaderciliği, ezeldeki belirlenim üzerinden yaptıklarından hesap verme fikrini de tutarsız bir noktaya çekmekte gibidir. Zira yaptıklarım bütünüyle benim fiilim değilse, ya da diğer bir deyişle ben fiillerimin mutlak sahibi değilsem, o zaman âdil bir hesaptan bahsedilemez. Gelinen bu noktada ifade edilebilir ki, popüler dindarlığın etkin kaynaklarından olan ilmihâller, ahlâk ve sorumluluk dengesini kişisel özgürlük anlayışı üzerinden kabul edilebilir bir sınıra çekmeyi de başaramamıştır. Nitekim ilmihâl dindarlığında insan fiilleri söz konusu olunca ibre daima ezelî belirlenime doğru kaymakta, özgürlük ve sorumluluk dengesi bir türlü ahlâkî sınırlara çekilememektedir. Bu minvâl üzere işleyen bir insan algısı, sonuçta yaptıklarının sorumluluğunu taşımayan ve sahte özgürlük alanları üzerinde dolaşan bir kişilik tipi ortaya çıkarmıştır. Diğer bir ifadeyle ilmihâl kaderciliği insanın iradeli eylemlerini sorumluluğun gerek şartı olarak kabul etmediği içindir ki, ilgili eserlerin tedrisinden geçen dimağların yaptıklarının bütünüyle kendi fiilleri olduğu bilincine ulaşmaları mümkün görünmemektedir. İlgili tasavvur üzerinden tesis edilmiş olan bu algının da kişisel hürriyet ve sorumluluk dengesini kurma ihtiyacı sorun olarak bile algılanmamıştır. Nitekim popüler dindarlığın sorumlu insan olgusu aleyhine tek taraflı olarak işlediği bu algının olası zararlarına değinmiş olan bazı kişiler, sağlıklı bir kader algımızın esasında Allah-insan ilişkisindeki temel bir denge olan "özgürlük" değeri üzerinde tesis edilmesi gerektiğini dile getirmektedirler. Onlara göre, özgürlük değerinin temeli denge üzerinde kurulmalıdır ki tarafların haksızlığa dûçar olmalarının önüne geçilebilsin. Ancak bu dengenin insan lehine bozulması da günümüz dünyasında sıkça örneklerini gördügümüz büyük sorunların yaşanmasını gerekli kılabilir. O nedenledir ki kader algımızın özgürlük değeri üzerinde, özgürlüğün de ahlâkî edimler üzerinde inşâ edilmesi mutlak zaruret olarak kabul edilmelidir. Mamafih yukarıda ifade edilmiş olan dengeyi destekleme mahiyetinde insan eylemlerinin ahlâkî sınırları olması gerektiğini dile getirmiş olan Atasoy Müftüoğlu, icrâ edilecek her eylemde mutlak surette "özgürlük ahlâkl"nın kuşanılmasını, aksi takdirde büyük yıkımların olabileceğini söylemektedir: "Hayatta hiçbir şey, ahlâkî sınırları olmayan "özgürlük” kadar yıkıcı olamaz." Atasoy Müftüoğlu, Travmatik Varoluşlar, İstanbul 2013. 
dindarlıklarda kitapta yazılan şeyin tahsili kadar, onun mutlak doğruluğu da hedef davranış olarak verilmektedir. Bu yüzdendir ki hedefe kilitlenmiş bir tasavvurun, kendisine gösterilmiş olan hedefi tartışma lüksü olmayacağı aşikâr bir yönelim olarak durmaktadir.

\section{II-Mızraklı İlmihâl Kültürü}

Denilebilir ki hâlihazırda Osmanlı bakiyesi olan bu topraklar üzerinde sahip olduğumuz geleneksel din anlayışının kökenlerini tespit edebilmek için bazı eserlerin yardımına başvurmak zorundayız. Kanaatimizce bu gibi eserlerin oluşturduğu din anlayışı, uzun yıllardır ilgili kurumlar aracılığıyla sabit ve değişmez doğru kabul edilerek halkın önüne getirilmiştir. Müslüman halk ise, ögreticiler tarafından kendisine sunulan bu din anlayışını gönülden benimseyerek kendi açısından kabul edilebilecek olan bir dindarlık ölçüsü de geliştirmiştir. Dahası, bu eserlerin oluşturduğu din algısı, zaman içerisinde bütünüyle dinsel hakikatin yerini alarak, kendisi dışındaki dinsel algıları, "ehl-i bid'at", "ehl-i dalal", "sapık", "batıl" ...gibi bazı suçlayıcı terimler vasıtasıyla tamamen ötekileştirmiştir. Öyle ki varlığını devam ettirebilmek için kendi çapında haklılık devşirmiş olan bu yapı, yol boyunca siyasî otoritenin de büyük yardımını görmüştür. Belki de kurumsal kimliğini tesis edebilmek için bu yola başvurmuş olan geleneksel dinî düşünce, kendi dışındaki dinî eğilimlere kapalı bir toplum oluşturmayı da başarmış gibidir.

Yukarıda çerçevesini çizdiğimiz düşüncenin geleneksel kaynakları üzerinde yapılacak olan çalışmalar, halk dindarlığının mutlak surette bazı eserlerin etkinlik alanları üzerinden şekillendiğini gösterecektir. Bu yüzden yalnızca sıradan halkın kabulleri üzerinde değil, eğitim-öğretim süreçlerinde de etkisinin daha yoğun olduğu bazı eserlerden bahsedilebilir. Kanaatimizce ilgili süreci besleyen Popüler dindarlığın en önemli eserlerinden birisi de "Mizraklı İlmihâl"18 adı verilen eserdir. Nitekim yüzyıllardır içerisinde yetiştiğimiz halkın din anlayışını irdelediğimizde açıkça görüleceği gibi, toplumumuzun din algısı nerdeyse "mızraklı ilmihal dindarlı̆̆ı" üzerinde şekillenmiş gibidir. Bu sonucun ise pek

\footnotetext{
${ }^{18}$ XVI. Yüzyıldan sonra kaleme alındığı düşünülen "Mızraklı İlmihâl”, Osmanlı eğitim-öğretim ve ilim dünyasındaki ilmihâl geleneğinin ilk ve önemli eserlerinden kabul edilmiştir. Esasında anonim olan bu eser, sadece kendi devri itibariyle değil, sonraki dönemlerde de en çok okunan, ezberlenen, cami ve Kur'an kurslarında öğretilen eserlerin başında gelmektedir. Bu yüzden de uzun dönemler itibariyle Osmanlı halkının din anlayışını etkilemekle kalmamış, dindarlık ölçeğini de belirlemiştir denilebilir. Mızraklı İlmihâl, yakın döneme kadar gerek camilerde, gerekse de kurslarda gayr-i resmi bir şekilde de olsa okutulup-öğretilmek suretiyle, aynı medrese eğitimini uzun süre devam ettirmiş olan ve Osmanlı'nın devamı olan yeni Türkiye Cumhuriyetinin Müslüman halkının da din anlayışını etkilemiştir. Mızraklı İlmihâl, kendi dönemi içinde ilk örnek olmasının yanında, bunun yanında "Miftahu'l-Cenne" ismiyle de meşhur olmuştur. Bu esere "mızraklı" denilmesinin sebebi olarak, eserin baskılarında kapak ya da ilk sayfalarında görülen "mızrak" ya da "sancak" şeklinden olabileceği gibi, eserin bilinen tek nüshasında (Süleymaniye Ktp. Yazma Bağışlar, nr. 1164) görülen "Mızraklı Efendi" ibaresi de olabilir denilmektedir. Mızraklı İlmihal, kullandığı sade dil ve basit anlatımı yüzünden kolaylıkla ezberlenmiş ve çok uzun yıllar, hatta günümüzde bile Müslümanların din tasavvurunu derinden etkilemiş bir eserdir. Bkz. Hatice Kelpetin Arpaguş, Osmanlı Halkının Geleneksel İslâm Anlayışı ve Kaynaklarl, İstanbul 2011, s. 38-39; Kurt, age, s. 97.
} 
yadırganmaması gerekmektedir. Zira dinsel hakikatleri halkın önüne getiren taşıyıcıların beslendiği temel kaynaklar, genellikle bu tür eserler olmaktadır. Gelinen bu noktada ifade edilebilir ki, bugün itibariyle bile cami kürsülerinden anlatılan dinsel değerlerin ilgili dinî yaklaşımdan pek de arındığ söylenemez.

Bilindiği gibi ilmihâller, önce ahlâk ve şahsiyet eğitimi üzerinde değil, önce inanç ve ibadet kazanımı üzerinde hazırlanmış olan eserlerdir. Bu kurgunun bir noktaya kadar anlaşılır olduğunu da söyleyebiliriz. Belki de eser sahipleri, bütün iyi niyetiyle, herhangi bir kişinin iman ve ibadetinin tam olması hâlinde zaten ahlâklı olacağı düşüncesini taşımaktaydı. Hatta onlar için ahlâk denilen şeyin esasında iman ve ibadetten ibaret olduğu da söylenebilir. O yüzden de kişiler, bu iki temel değeri yerine getirirlerse mutlaka ahlâklı olurlar diye düşünülmüştür. Kanaatimizce bu yargı üzerinden hareket eden yazarlar, ahlâkî konuları ya hiç işlememişler, ya da âdâb-1 muaşeret anlamındaki günlük davranış kalıpları üzerinden ifade etmişlerdir. Hâlbuki sağlıklı bireylerin yetişmesi sürecinde daha kişilik oluşurken ya da oluşmadan inanç, ibadet ve ahlâk dengesi kurulmalıdır. Bu denge üzerinde yapılacak öğretimin esas gayesinin de inanç ve ibadetin şeklî icrasının mükemmelliğinden çok, ahlâkî kazanımların tedrisi olması gerektiği düşünülmelidir.

Mızraklı ilmihâl mantı̆̆ının esas alındığı eserlerde dinsel öncelikler, inanç, ibadet ve ahlâk gibi farklı alanlar üzerinden tanımlanmıştır. Zira bu eserlerin yazımındaki esas gaye, ilgili sıranın korunarak Müslüman halka iman ve ibadetlerin öğretiminin üzerinden bir tedrisat yapmaktır. Bu yüzdendir ki, ilgili eserler, bu konuların öğretimi amacı üzerinden bizce gereksiz detaylarda boğulmuştur. Neticede ise yaptığından emin olmak için kılı kırk yaran şüpheci bir Müslüman tipi ortaya çıkmıştır. Daha doğru bir ifadeyle, dinsel hayatın merkezinde takdim edilmiş olan ibadetlerin gerekli-gereksiz ayrıntılarında kaybolan bir kişi, ahlâk konularına gelmeden eğitimini tamamlamakta, bu yüzden de ahlâkî kazanımlardan bütünüyle habersiz, kuralcı bir Müslümanlık baş göstermiştir denilebilir. Nitekim Türk Müslümanlığının besleyici kurumlarından olan kuran kursları, öğretimine mehaz teşkil ettikleri bu eserler üzerinden şekilci bir Müslümanlık algısı da oluşturmuştur. Öyle ki ilgili dindarlığın temel kaynaklarından olan bu eserlerde bütün ibadetler, her şeyden önce fayda zarar, kazanç-kayıp dengesi üzerinden anlatılmıştır. Bu sayede marketing felsefesi üzerinden adeta bir "hesap cetveli"ve "sevap dükkânı" gibi çalışan yeni bir din anlayışı kurumsallaşmıştır. Kurumsallaşmış bu anlayışın tanıtım öğesinin de genel olarak "diyanet dindarlığı" olduğu söylenebilir. Onun içindir ki, ülkemizdeki yüz binden fazla camilerdeki vaazlar, genel olarak bu üslûpla anlatılmaya devam etmektedir.

Mızraklı İlmihâl dindarlığının yerleştirmeye çalıştığı esas şeyin, yapılmış/yapılacak olan ibadetler üzerinden elde edilecek pek çok sevabın olduğu ve bu sevapların da rakamsal bir karşılıkla ifade edilmiş olduğu gerçeğidir. Diğer bir ifadeyle, Mızraklı İlmihâl dindarlığında inanç ve ibadet davranışı, ahlâkî kazanıma mâtuf eylemler değil, doğrudan sevap kazanımına müteallik işlerden görülmelidir. $\mathrm{Bu}$ konudaki teşhisimizin doğruluğu için aşağıdaki alıntı kâfi gelecektir kanaatindeyiz: "Namazda yapılan şeylerin karşılığı: Bir âdem(kişi) namazda "Eûzü-Besmele" okuduğunda, Allahüazimüşşan o kula bedeninde olan 
killar sayısınca sevap verir. Ve Fâtiha-i Şerife okuduğunda AllahüTeâla Hazretleri o kula kabul olmuş hac sevabı verir. Ve rükua vardı̆̆ında, Allahüazimüşşan nice bin altın sadaka etmiş sevabı verir, rüku'da sünnet üzere üç kere tesbih ettiğinde o kula Allahüazimüş̧an Hazretleri, gökten inan yüz dört kitabı okumuş kadar sevab verir. "Semiallahu limen hamideh" dediğinde, o kulu Allahüazimüşşan rahmet deryasına gark eder ve secdeye vardiğında, o kula Allahüazimüşsan, insanlar ve cinler adedince sevap verir. Secdede üç kere sünnet üzere tesbih ettiğinde, o kula Allahüazimüşşanın fazileti çoktur, ama (âlimler) bir kaçını beyan etmişler: 1.Fazileti: Arş ve Kürsü ă̆ırlığı kadar sevap verse gerekir. 2.Fazileti: Allahüazimüşşan'ın o kulu mağfiret etse gerektir. 3. Fazileti: O kul öldüğ̈̈nde Mikail (Aleyhi's-Selam) o kulun kabrini klyamete kadar günde bir kere ziyaret etse gerektir. 4.Fazileti: Kryamet gününde Mikail (Aleyhi's-Selam) o kulu mübarek kanadı üzerine alıp şefaat edip, Cennet-i Ala'ya götürse gerekir."19

Aynı şekilde ilgili eserlerde ibadet yapmayanların cezalandırılması üzerinden bir tecziye kültürü de geliştirilmiştir. Hâlbuki "takva sahibi bir kişiliğin" yetiştirilmesinde başat unsurlardan olan namazın terkinin dünya hayatında bir cezalandırılmaya gidilmemesi olgusu, Kur'anî bir hakikat olarak karşımızda durmaktadır. Bu durum, namaz eyleminin esasında ahlâkî bir gelişmenin olmazsa olmaz parçası olduğunu da göstermektedir. Dahası, namazsız bir Müslümanın kâmil ve ahlâklı bir Müslüman olmayacağının doğru bir çıkarım olduğu kadar, namazı şekil unsurlarından ibaret gören ilmihâl dindarlığının da bütünüyle doğru olmadığını göstermektedir. Belki de bu yüzden ilgili eserlerde namazın vaktini geçirip kılamayanlara kabirde olan üç zarardan bahsedilerek, icad edilen bir "kabir azabı" üzerinden aşağıdaki gibi köklü bir korku salma yoluna gidilmiştir: "1.Kabri (kendisini) sıkar, kemikleri birbirine geçer. 2.Kabri ateş dolar. 3.Onun üzerine bir ejderha musallat olur. Onun adına akra derler. Onun elinde bir kamçı olur ki, ateşten bir günlük uzunluğu var. Onunla bir kere vursa, yerin dibine geçer, yine çıkar, bir daha vurur. Böylece klyamete kadar o kimseye azap edilir., ${ }^{20}$

Görüldüğü kadarıyla Mızraklı İlmihâl'de bütünüyle yüzeysel olarak ele alınmış olan bir ahlâk konusu bulunmaktadır. Ancak bu bahis, Müslüman bireyin gerek kendisi, gerekse de çevresinin inşâsı için gerekli olan kazanımlar üzerinden değil, sığ bir alanda "ahlâk-ı hamide", yani "güzel ahlâk" formu üzerinden "âdap" ve "edep" boyutunda ele alınmıştır. Bu yüzdendir ki ilgili eserlerin bu bölümlerinde "günâh-ı kebâir"den, yani büyük günâhlardan uzak kalmak, ahlâklı olmanın yegâne şartı olarak ifade edilmiştir. ${ }^{21}$ Hatta daha da ileri gidilerek güzel ahlâklı olmanın temel şartının "Ehl-i Sünnet itikadına sahip olmaktır."22 şeklinde açıklandığını görmekteyiz. Bu algıya göre ilgili düşünsel eğilimin dışında kalan Müslümanlar, hatta diğer din mensupları ahlâklı olma şansından yoksun kalmaktadırlar. Mamafih inanç ve ibadetin bütünüyle ahlâklı olmanın bileşeni olarak görüldüğü bu algının ürettiği bazı sorunların olması kaçınılmazdır.

\footnotetext{
${ }^{19}$ Mizraklı İlmihâl, İstanbul ts., s. 78.

${ }^{20}$ Mizraklı İlmihâl, s. 72.

${ }^{21}$ Mizraklı İlmihâl, ss. 134-138.

${ }^{22}$ Mizraklı İlmihâl, s. 134.
} 
Kanaatimizce inandığı gibi yaşamayan Müslümanların varlığı, öncelikli olarak bu algıdan neş'et etmektedir. Çünkü inanıp ibadet eden her kişi, otomatik ahlâklı ise, bunun dişında tanımlanmış olan bir ahlâk zaten gereksiz bir ayrıntı olarak duracaktır. O yüzden de kendisinin dışındaki herkes, mutlak surette güzel ahlâktan yoksun olan kişiler mesabesindedir. Tabiidir ki güzel ahlâk'ın sadece kendisinde olduğuna inanan bir kişiliğin, başkasından alacağı herhangi bir şey de olmaz.

Mızraklı İlmihâl dindarlığının diğer bir ahlâk ölçüsü, haklı olarak Hıristiyanlıkta olduğu veçhile atalardan miras alınan bazı günâhların olabileceği düşüncesini bütünüyle reddetmektedir. Bu düşünce şekline göre hiçbir günâh atalardan tevârüs edilemez. Ancak ilgili eserlerin temel kabullerinden olan bazı yaklaşımların ahlâk formu içerisinde ele alınmasının imkânı da yok gibidir. Nitekim: "Bir kimse, Adem Aleyhisselam 'buğday' yemeseydi, biz şâki olmazdık dese kâfir olur.",3 cümlesinde olduğu gibi, Cennetten kovulmayı "buğday yeme" üzerinden anlatmakla, Hz. Âdem'in biz oğulları için örnekliğini tehlikeye düşürmektedir. Hâlbuki Cennetten kovulmanın gerçek nedeni olduğunu kabul ettikleri suç, esasında insanın dünya üzerindeki eylemselliğinden çıkan günâhlardan başka bir şey değildir.

Kadın erkek ilişkisini erkeklerin otoriterliği üzerinden tanımlayan Mızraklı İlmihâl dindarlığı, bazı konularda kadınların dövülebileceğini kabul etmekle, başta nebevî örnekliği hiçe sayan negatif bir öğretim modeli benimsemiş gibidir. Oysaki bu anlatım üzerinden aile içerisinde belli oranlarda şiddetin benimsenmiş olması, temelinde aile saadetini parçalayan bir unsur olarak görülmelidir. Mamafih ilgili eserde geçtiği şekliyle "kişi hanımını üç yerde dövebilir: Namazdan ötürü, döşeğine gelmediğinden ötürü ve izinsiz dışarlya çıktı̆̆ından ötürü. "24 tarzındaki bir kabul, eşler arasındaki huzurlu ilişkinin her an şiddete dönüşebildiği bir ahlâk erozyonunu da beraberinde getirmektedir. Zira eşini dövmenin kocaya bir hak olarak verildiği bu gibi aile yapısından ise ahlâklı ilişkilerin beklenmesi düşünülemez. Dahası, bu ortamda yetişen bireylerin de dayağa karşı bağışıklık kazanmaları hasebiyle, kişisel ve toplumsal ilişkilerde sıklıkla şiddet seçeneğini kullanması, ya da kendisine uygulanan şiddeti normal görmesi sorunuyla karşı karşıya kalabilmekteyiz.

Denilir ki Müslüman dünyanın en büyük sorunlarından birisi de "kadın" sorunudur. Kanaatimizce bu yargı çok da yanlış bir hüküm değildir. Çünkü yirmi birinci asrın bu demlerinde bile bazı kurumlarda okutulan eserlerde aşağıdaki gibi kabullere rastlamaktaysak, Müslüman toplumların "kadın sorunu"nu hâlâ âdil ve dengeli/eşit bir şekilde çözemediğine hükmetmeliyiz. Şimdi ilgili eserlerde yalnızca Müslüman toplumlarda değil, bütün toplumlarda da kişisel ahlâkın taşıyıcısı olan büyük bir kitle için ifade edilmiş olan ahlâkî zaaflardan bir demet sunabiliriz.["Cennet ehlinin çoğu fukara, Cehennem ehlinin çoğu kadınlardır.",25 "Kadın, kocasından dört mertebe aşağı olması gereklidir. Biri yaşı, biri boyu, biri mall, biri hısımı veya akrabası. Dört şeyde de erkekten üstün olmalıdır: Biri güzel olmalı, biri edepli olmalı, biri huyu güzel olmalı ve biri şüphelilerden sakınıcı

\footnotetext{
${ }^{23}$ Mizrakl İlmihâl, s. 146.

${ }^{24}$ Mizraklı İlmihâl, s. 159 .

${ }^{25}$ Mizraklı İlmihâl, s. 157.
} 
olmalı. Ve genç kızları koca(yaşlı) kimselere vermemeli, adeta fesada sebep olur." 26 "Bir kadın güzel kokular ile namaz kılmak için mescide gelse, o kadının namazı kabul olmaz. Ta ki varıp cenabetten gusül eder gibi gusül edinceye kadar. Taşraya çıkıp halka görünmek de böyledir."27 Cima esnasında besmele denmezse, şeytan onun cinsel uzvuna oturarak hanımı ile cem olur yani birleşir."’] ${ }^{28}$

Kanaatimizce bugün itibariyle Peygamber algısının "beşer" niteliğini aşarak "yücelik" formuna dönüşmüş olmasının başlıca nedeni, bu gibi eserlerin uzun yıllardır kurumsallaştırdığı şekliyle Yüce Kitabimiz Kur'an'dakinden bütünüyle farklı sıra dışı bir Peygamber algısının varlığıdır. $\mathrm{Bu}$ algının başa karakteri peygamberin insanüstü özelliklere sahip bir kişilik olduğunun açklanmış olmasıdır. Zira bu algıya göre Allah Resulü, asla bir insan gibi değildir. Onun insanüstü nitelikleri vardır. Bu niteliklerine binaen onun varlığı sadece bedenden ibaret görülemez. Nitekim aşağıda verildiği şekliyle gerek Cebrail, gerekse de Yüce Allah ona bu nitelikleri üzerinden farklı bir şekilde hitap etmişlerdir. "Resulullah (Sallallahü Aleyhi ve Sellem) hazretlerinin Mirac'a çıktığı gece Cebrail'e hitabı: "Ya karındaşım!"(Ey Kardeşim) Cebrail), ${ }^{29}$ Cebrail'in Hz. Muhammed'e hitabı ise: "Ya Habiballah!” (Ey Allah'ın Sevgilisi) ${ }^{30}$ şeklindedir.

Bu cümleden olarak denilebilir ki, popüler dindarlığın öğretildiği pek çok eserde benzeri yaklaşımların bulunduğu şu nitelikler, Hz. Peygamber için tanımlanmış üstün vasıfları içermektedir: “Aleyhi's-salatüve's-selam'a ait olan bazl sifatlar: 1 . Şefaati ehl-i kebâire ve ehl-i sağaire kapsamaktadır. 2.Validesinden sünnetli doğmuştur. 3.Büyük (tebevvül) ve küçük (tegavvut) abdest ettiğinde yer yutup misk gibi kokardl. 4.Mübarek gölgesi asla yere düşmedi. 5.Önünden gördüğünü arkasından da görürdü. 6. Mübarek ayă̆ kuma bassa, iz olmaz; taşa bassa, iz olurdu. 7.Mübarek cesedine müziyyat olan (eziyet veren) hayvandan bir şey konmazdl. 8.Asla ihtilam olmadl. 9.Her nereye gitmek murad eyleseler, onun temiz nuru ondan evvel varır idi. 10. Her kimin yanında dursa, mübarek boyu dört parmak yüksek gösterirdi. 11.Onun üzerinden bir beyaz bulut eksik olmazdl. 12.Uyusa uyansa abdesti bozulmaz idi. 13.Doğduğu gibi secdeye vardl. 14.Onun temiz vücudu gelmezden önce göklere çıkan şeytanlar, o geldikten sonra çıkamaz oldular. 15.Parmaklarını suya sokunca su fişkırır, mübarek parmaklarıyla da ayı iki parça etmiştir."’31

Bütünüyle ilmî destekten yoksun bir şekilde anlatılan ve esas olarak da rivayet ve duyum üzerinde dile getirilen pek çok husus, ilmihâl dindarlığının etkin eserlerinden olan Mizraklı İlmihal'de temel bir ahlâkî kabul olarak zikredilmektedir. Mamafih başlangıç olarak hedef kitlesinin eğitimi üzerinde odaklanan bu hususlar, "hurafe" denilen pek çok algının da kurumsallaşarak yaygınlık kazanmasının basamağını teşkil etmektedir. Öyle ki sıradan halkın

\footnotetext{
${ }^{26}$ Mizraklı İlmihâl, s. 155.

${ }^{27}$ Mizrakl İlmihâl, s. 156.

${ }^{28}$ Mizrakl İlmihâl, s. 156.

${ }^{29}$ Mizraklı İlmihâl, s. 77.

${ }^{30}$ Mizrakl İlmihal, s. 77.

${ }^{31}$ Mizraklı İlmihâl, s. 122-123.
} 
yaşamı üzerinde etkin olan bu anlatılar, hem ahlâklı olmanın prototip örnekleri, hem de sevap kazanmanın birincil ayağı olarak da açıktan dile getirilmişlerdir. Nitekim ilgili eserlerde, edebe mugayir davranışları yasaklamak için halkı "uyarı" babında dile getirilmiş olan bazı hususlar şu şekilde ifade edilebilir: "Yoksulluk sebepleri: namazda tâdil-i erkânı terk etmek, ${ }^{32}$ ayakta bevletmek, cünüp iken yemek yemek, ekmeğin ufağına basmak, soğan ve sarımsak kabuğunu ateşte yakmak, âlimlerin önünde yürümek, atasını ve anasını adıyla çağırmak, ağaç ve süpürge çöpüyle dişini kurcalamak, elini balçık ile yıkamak, eşik üzerinde oturmak, bevlettiği yerde abdest almak, çană̆l ve çömleği yıkamadan yemek koymak, esvabını üstünde dikmek, yüzünü eteği ile silmek, aç iken soğan yemek, evinde örümcek komak, sabah namazından sonra mescitten aceleyle çıkmak, erken pazara varıp pazardan geç çıkmak, yoksul kimseden ekmek satın almak, ataya ve anaya kötü dua etmek, çıplak yatmak, kap kaçă̆ı örtüsüz koymak, kandili üflemek suretiyle söndürmek."33

Özellikle içerisinde yaşadığımız toplum için ifade edecek olursak, Mızraklı İlmihâl dindarlığ 1 , bugün itibariyle öğrenim materyali olan pek çok kabulün değer olarak yerleşmesini başarmıştır denilebilir. Meselâ ' 54 Farz' algısı, ${ }^{34}$ buna örnek olarak verilebilir. Aynı şekilde sahîh Müslümanlığın gerek ölçüsü olarak sunulan "Ehl-i Sünnet ve'l-Cemaat" kabulü de bu eserlerin kutsamış oldukları bir dinsellik algısıdır. Zira onlara göre Ehl-i Sünnet demenin manas1: "Resulullah'ın (Sallallahü Aleyhi ve Sellem) Ashabu ve cemaati her ne itikat (inanç) üzere oldularsa, ben de o itikat (inanç) üzere oldum' demektir. "35 Nitekim ilgili eserde popüler dindarlığın sahihlik kriteri olan "Ehl-i Sünnet dindarlığg”"nın temel adımları şu şekilde ifade edilmiştir: "Ehl-i Sünnet olanların alametleri şunlardır: 1.Fâsık demeyip imama uyar. 2.Mest üzerine mesti caiz görür. 3.Ashab ve Resulullah'a ar veriri, söz söylemez. 4.Padişaha kılıç çekmez. 5.Hayrı ve şerri Allah'u Teala'dan bilir. 6. Ehl-i Kıble'yi tekfir etmez." ${ }^{36}$ Kendileri için bu denli kapsayıcı bir sahîhlikten başkalarının da doğru olabileceği bir din algısının çıkması mümkün değildir. O yüzdendir ki ilgili eserlerde hakikatin merkezine yerleştirilmiş bir Ehl-i Sünnet algısı kendisi dışındaki her oluşumu "öteki” olarak tanımlamak durumundadır. Realitenin de bu minvâl üzere işlediği hesaba katılırsa, bu yapıdan ötekilerin de hakikat üzere olabileceği ahlâklı bir yapının oluşması mümkün görünmemektedir.

İlmihâl dindarlığının geleneksel anlamda kabul edilen her türlü değeri iman esası olarak tedâvüle çıkardığı görülmektedir. Halkın kabulleri üzerinde kadîm bir destek de oluşturmuş olan bu eğilim, ataların kabulleri üzerinden sahih bir dinsel algının oluşturulmasını da esas kabul etmektedir. Zira bu algının temerküz ettiği her değer, gerek inanç esası olarak, gerekse de ibadet esası olarak geçmiş dindarlığın onayladığı bir şekilde yaşanmalıdır. Buna karşı çıkmak, dine karşı çıkmak şeklinde algılanmaktadır. Mamafih bu algıya örnek olarak verilecek bir husus, ilgili dindarlık ölçeğinde inanılması gereken bir unsur hükmünde olan

\footnotetext{
${ }^{32}$ Mizraklı İlmihâl, s. 74.

${ }^{33}$ Mizraklı İlmihâl, s. 84-85.

${ }^{34}$ Mizraklı İlmihâl, ss. 86-89.

${ }^{35}$ Mizraklı İlmihâl, s. 23.

${ }^{36}$ Mizraklı İlmihâl, s. 94.
} 
“Sırat Köprüsü" anlayışıdır. Bu anlayışın mutlak surette hakikati ifade etmiş olduğu her ortamda kişilerin karşısına "Sırat Köprüsü üzerindeki yedi sual" tarzında bir gerçeklik algısı oluşturulmuştur. Sırat Köprüsü inanışının yedeğinde gelişmiş olan bu algıya göre ilgili sualler şunlardır: "1-(Ehli Sünnet inancına ters düşen inancının olup olmaması yönünden) imandan, 2.(Dinin direği olması yönünden) namazdan, 3.(Farz ve adak oruçlarını tutup tutmadığı yönünden) oruçtan, 4.(Dinen zengin olup ömründe bir kere Arabistan'a gidip gitmediği yönünden)hacdan, 5.(Dinen zengin olup, malının kırkta birini verip vermediği yönünden) zekâttan, 6.Kul haklarından, 7. Gusülden, istincadan ve abdestten." ${ }^{37}$

Geleneksel dindarlığın yürürlükte olan siyasî kodlarına göre "hilafet 30 yıldır. "38 Zira bu algının oluşmasını sağlayan destek unsurlarından birisi de ilmihâllerdir. Oysaki Mizraklı İlmihâl kültürü içerisinde neredeyse mutlak hakikat olarak kabul edilmiş olan bu unsurlar, sünnî dünyanın siyaset algısından başka bir şey değildir. Ayrıca, ilgili algının tesis etmiş olduğu bir yaklaşım da "evliyanın kerameti de haktır." 39 gerçeğiyle ifade edilmektedir. Yine bu çeşit dinsellikte Peygamberler ile sıradan insanlar arasında "velî/evliya" denilen bir insan kümesi var edilmiştir. Sıradan kişiler, Peygamberlerin destekçisi olan bu insanlar üzerinden dinlerinin hakikatini öğrenebilirler.

Mızraklı İlmihâl dindarlığı, sünnet kavramı üzerinde sıklıkla durmak suretiyle, kişileri sünnetin kuşatıcı kollarına sürüklemiştir denilebilir. Bu meyanda klâsik ilmihâl tanımının dışına çıkmak suretiyle, özellikle de bazıları üzerinden sürekli işlenmesi gereken bir sünnet/nafile ibadet kültürü oluşturmuştur denilebilir. Nitekim Mızraklı İlmihâl, "Sünnet-i Müekkede" tarifini: "Resulullah'ın devamlı olarak işleyipnâdiren terk ettiği, farz ve vacip olmayan ameller" ş̧eklinde, "Sünnet-i Gayri Müekkede" tarifini ise: "Resulullah'ın çok defa yapıp bazen terk ettiği sünnetlerdir." "40 şeklinde dile getirmiştir. Hâlbuki bu tarifler klâsik ilmihâllerde "Resulullah'ın pek az yapmadıkları" ve "bazen yaptıkları" şeklinde ifade edilmektedir. ${ }^{41} \mathrm{Ne}$ gariptir ki halkın geneli de öğreticilerin yönlendirmesiyle birinci tip eserlerin yaptığ tanımı esas alarak, "terk edilmemesi gereken sünnet" algısının oluşmasına katkıda bulunmuşlardır.

Denilebilir ki klâsik kader algısının oluşmasında önemli bir yeri olan Mızraklı İlmihâl kültürü, bireyin kendi iradesiyle yapıp etmelerini bile ezelî ilim algısı çerçevesinde kabul etmektedir. Kanaatimizce bu eğilimin kökeninde olan gerçek endişe, Yüce Allah'ın gereği gibi tenzihi sorunu yatmaktadır. İnsan eylemlerinin ezelde takdir edilmesini bireyin özgürlüğüne halel getiren bir adım olarak kabul etmeyen bu anlayış, kişisel eylemleri bütünüyle iradî seçenekler içerisinde değil de, Cenâb-1 Allah'ın takdiri içerisinde ele almaktadır. Dahası bu durum, ilgili

\footnotetext{
${ }^{37}$ Mizraklı İlmihâl, s. 29.

${ }^{38}$ Hz. Ebû Bekir, 2 sene, 3 ay 20 gün; Hz. Ömer Faruk, 10 sene, 6 ay, 4 gün; Hz. Osman Zinnûreyn, 11 sene, 11 ay, 18 gün; Hz. Ali, 4 sene, 10 ay, 1 gün; Hz. Hasan, 6 ay. Cümlesi otuz y1ldır. (Bkz. Mızraklı İlmihâl, , s. 95).

${ }^{39}$ Mizraklı İlmihâl, s. 95.

${ }^{40}$ Mizraklı İlmihâl, s. 99.

${ }^{41}$ Ömer Nasuhi Bilmen, Büyük İslâm İlmihâli, s. 51.
} 
eserler için herhangi bir sorun da teşkil etmemiştir. Nitekim bu algıdan hareket eden bu gibi eserlerde "kader" ve "kaza" inancı şu şekilde detaylandırılmıştır: "Kadere Iman: Hayır ve şer olup ve olacak cümlesi Allahüazimüşşan'ın takdiriyle ve dilemesiyle ve yaratmasiyla ve levh-i mahfuza yazmast ile olduğuna inandım, iman getirdim. Asla kalbimizde şek ve şüphe yoktur."42

Mızraklı ilmihâl dindarlığ 1 içerisinde görülen bir diğer sorun ise, amaçların değil, araçların kutsal kabul edildiği bir dinsel eğilimi besler tarzda kuralların konulmuş olmasıdır. Bu konuya örnek olarak verilecek en önemli şey, kendi döneminde “ă̆ız ve diş temizliği ağız ve diş temizliğinden ziyade, misvak kullanmanın faziletlerine değinilerek, bugün itibariyle aynı işi gören diş fırçaları bütünüyle göz ardı edilmiştir. Nitekim Mızraklı İlmihâl'de misvak kullanmanın faydaları şu şekilde dile getirilmiştir: "Misvak kullanmak, ölüm anında kelime-i şahadeti söylemeye sebep olur, safrayl keser, ă̆ız ă̆rısını giderir, başın damarlarını kuvvetlendirir, gözler nurlanır, güzel konuşur, şeytan gamlanır, Misvak ile kllınan iki rek'at namazın sevabl, misvaksız kılınan yetmiş rek'at namazın sevabından çok olur. "43

Son olarak ifade edilebilir ki Mızraklı İlmihâl dindarlığının önemsediği pek çok değer, bugün itibariyle insanlığın gelmiş olduğu seviyeyle uyuşmaz nitelikteki bildirimlerdir. Tıp ve diğer bilimlerin temel ilkelerine bütünüyle aykırı olan pek çok hüküm, ilgili eserlerde Müslüman ahlâkının oluşması için "kaçınılması gereken şeyler" içerisinde ele alınmıştır. Anlaşıldığı kadarıyla kendi zamanı içerisinde etkin bir öğretim materyali olarak kullanılan bu bildirimlerin genel geçer bir kabule dönüşmesi, kitapta yazan her şeyi doğru kabul eden bir anlayış sayesinde olmuştur. Bu aşamada Kur'an-1 Kerim üzerinden öğrendiği din sayesinde kalıcı bir ahlâk modeli geliştirecek olan herkese tuhaf gelebilecek olan bu kabullerden bazılarını şu şekilde ifade edebiliriz: "Yemeğin başında besmele çekilmezse yenilen yemek bedende hastalık olur."44 Devamında ise: "Slcak yemek yemenin bazı zararları şunlardır: Kulă̆ı să̆ır olur, benzi sarı olur, gözlerinin feri olmaz, dişleri sararır, ă̆zının lezzeti olmaz, karnı doymaz, anlayışı az olur, akl az olur, bedeninde hastalık olur. "45 Denilebilir ki bu gibi anlamsız anlatılar üzerinden kabul edilebilecek olan bir dindarlık şekli, sonuçta ne öğreticinin kendisine, ne de muhatabına hiçbir yarar sağlamayacaktır. Hatta dediğine inanılmayan bir öğreticinin de ahlâkî kazanım adına başkalarına herhangi bir şey katması da söz konusu olamaz.

\section{III-Durum Tespiti}

Hâs1l-1 kelâm olarak ifade edilebilir ki, ilmihâl kültürünün hayatı kuşatan bütüncül bir ahlâk oluşturamamasının nedenleri olarak şunları söyleyebiliriz:

İlmihâller, genel olarak hayatı "parçacı" bir tasavvur üzerinden algılama eğilimindeki eserlerdir. Onlara göre insanın "din işleri” ve "din dışı işleri” gibi

\footnotetext{
${ }^{42}$ Mizraklı İlmihâl, s. 109.

${ }^{43}$ Mizraklı İlmihâl, s. 125-126.

${ }^{44}$ Mizrakl İlmihâl, s. 100.

${ }^{45}$ Mizraklı İlmihâl, s. 129-130.
} 
farklı iki alandaki eylemleri bulunmaktadır. Nitekim "inanç" ve "ibadet" dinin içindeki işlerden, bir kısım ahlâk ve diğer alanlar ise dinin mücavir alanındaki işler olarak görülmektedir. Bu yüzden de ilgili eserlerin baskın bir öğretim malzemesi olduğu her ortamda kişisel ve toplumsal hayatı kuşatıcı bir tasavvur elde edilememiştir.

İlmihâl kültürünün tesis ettiği dindarlık ölçeği, insanı kötü ve yanlış işlerden alıkoyması gereken ibadetleri, bir "eğitim malzemesi" olarak değil, bir "amaç "olarak gördüğünden, hayatın her anında yükümlü olunan sâlih amel olgusunu, sadece "borç" olan bir ibadet anlayışı üzerinden tanımlamıştır. $\mathrm{Bu}$ algının oluştuğu her kişilikte ibadetin şeklî icrası, ahlâkî kazanımların önüne geçebilmiştir.

Mevcut ilmihâller, "iman" ve "İslâm" kavramlarını bir bütünün iki parçası olarak değil, ayrı ayrı gerçeklikler şeklinde anladığı için, iman eden bir şahsın aynı zamanda iyi bir Müslüman olması gerektiğini atlamış görünmektedir. Bu yüzden de iman ettiği hâlde İslâmî duyarlılığı taşımayan hatta günâh işlemeyi içselleştirmiş Müslümanların varlığı sıklıkla görülmektedir. Dahası, bu kişilik tipinin üzerinden üç Cuma'nın geçmemesine büyük bir dikkat gösterdiğine de şahit olmaktayız.

Denilebilir ki ilmihâllerin öğretim kolaylığı babında kabaca tarif etmiş oldukları iman ve İslâm'ın şartları konusu, halk nezdinde kendi Müslümanlığı için 'yeter şart" olarak algılanmıştır. Bu yüzden de sıradan halk için bunları yapmak dindar bir kişiliğin temini hususunda bütünüyle yeterli görüldüğünden, içerisinde "ahlâk" olan her bildirim, zorunlu davranış ölçeği üzerinden algılanmamıştır. Nitekim bu yapının geliştirdiği şekliyle, içerisinde ahlakî değerlerin esas hükmünde olmadığı bir iman ve İslâm hayatı, ilmihâl dindarlı̆̆ üzerinden görünür olmuştur denilebilir.

Müslümanların önlerinde duran esaslı problemlerden birisi olan "kader" konusu, ilmihâl dindarlığının ölçeği üzerinden insan özgürlüğü aleyhinde işlenmiş gibidir. Nitekim bu yapının üretmiş olduğu insan tipi ise, kendi sorumluluğunda olan işlerin bile selâhiyetini almayan sorumsuz bir karakter üretmiştir. Müslüman ahlâkının genel kabullerine uymayan bu kişilik tipi, uzun süredir kişisel iradesiyle yaptığı her şeyin sonuçlarına katlanacak güçlü bir karakter de tesis edememiştir.

İlmihâl dindarlığını besleyen eserlerde anlatılan "Peygamber algısı", Kur'an'ın anlattığı Peygamber algısıyla bütünüyle çelişmektedir. Bu yüzden de bu eserlerin anlatımlarından, yaşanan hayatın içerisine taşınacak ve örnek alınabilecek bir Peygamber örnekliği çıkarılamaz. Çünkü bazı ilmihâllerin ortaya koymuş olduğu peygamber tasavvuru, beşerî hayatın dinamikleriyle açıklanamaz durumdadır. Dünya hayatında örneklik etmek üzere seçilmiş olan elçilerin beşer vasfı dikkate alınacak olursa, gizemli ve mucizevî bir yaşam şeklinin sıradan insan için örnekliğinden bahsedilemez.

Gayb konusu, ilmihâllerde beşerin bilebileceği bir alan olarak tanımlanmıştır. Peygamber, velî vb. kişilerin mucize, keramet ve başkaca nitelikler üzerinden bu alanda tasarruf edebilecekleri algısı oluşturulmuştur. Hâlbuki bu alandaki 
tasarrufun sadece Yüce Allah'ta olduğunun bilinmesi gerekmekteydi. Bu yüzden de Allah-insan ilişkisini düzenleyen bazı alanlar bu algı üzerinden bütünüyle tersyüz edilmiştir. Hâlihazırda hükmünü icra eden "ilm-i ledün" şeklindeki yapılanma bu alanın bazı kişilere hasredildiğinin açık göstergesidir.

Görüldüğü kadarıyla mevcut ilmihâllerde sorun çözme şekli, zaman zaman bilimin geldiği seviye üzerinden değil, yüzyıllar öncesinden önerilen çözümler üzerinden ilerleyen bir metodolojiye sahiptir. Hatta bazı konularda bilimsel olarak gelinen nokta bütünüyle göz ardı edilmekte, buna mukabil günlük hayatın dinamikleri geçmişin çözüm araçları üzerinden tarif edilmektedir. Mesela fitre, zekât, kuyuların temizliği, suların ahkâmı vb. konularda ilmihâllerde görülen çözüm şekilleri, zamanımızda ulaşılmış olan bilimsel buluşlarla uyuşmadığı açıkça görülmektedir.

İlmihâller, atalardan kalan dinsel mirasın kutsandığı eserler olarak bilinmektedir. Bir şeyin hakikat değeri, neredeyse geçmiş ulemanın onun üzerinde fikir serdetmesine bağlanmış gibidir. Eğer geçmiş ve geçmişin doğruları bu kadar kutsanacak ise, başta biz Türkler olmak üzere atalarının dinlerini terk eden herkes, bu konuda büyük bir yanlışın(!) içerisinde demektir. Oysaki kişileri sorumluluk sahibi kılan şeyler, geçmişten tevârüs edilenler değil, önlerinde duran kutsal metinlerin bildirimleridir.

Mevcut ilmihâllerin büyük bir kısmı, elinde olanın hakikat değeri taşıdığı kabulü üzerinden bir dindarlığın besleyici unsuru durumundadır. $\mathrm{Bu}$ yüzdendir ki ilmihâller, siyasî manada "hikmetinden sual edilmez" şeklindeki geleneksel din algısının yerleşmesini temin etmişlerdir. Dahası ilmihâller, bu hâliyle eleştiri ve sorgulama kültürüne büsbütün yabancı da durmaktadır. Bu nedenle de ilmihâllerin siyasî ve toplumsal hayata bakışı, mevcudu koruma refleksi üzerinden fonksiyonel olmaktadır. Nitekim mevcut otoriteye itaatin kutsandığı, isyanın ise zemmedildiğ bir dindar kişilik tipinin oluşmasına zemin hazırlayan ilmihâllerin varlığıyla karşı karşıya bulunmaktayız denilebilir.

Şeklî dindarlığın temel eserlerinden olan ilmihâller, gerek inanç konusunda, gerekse de ibadet konusunda davranışa dönüşebilecek bir dindarlık ahlâk1 oluşturamamıştır. $\mathrm{Bu}$ yüzden de ilgili eserler için formel Müslümanlığın gelişmesine büyük bir katkı sunduğu şeklindeki tespit bütünüyle yanlış bir öngörü olmasa gerektir. İbadetlerin şeklî ifası üzerinden tanımlanmış olduğu bu yapıdan kaynaklanacak olan dindarlığın, başkası için duyarlı bir Müslümanlık algısının gelişmesine katkı sunması zor gözükmektedir.

İbadetlerin görünür kazanımlarını öncelikli hedef alan ilmihâller, yapılan veya yapılamayan ibadetleri adeta "sevap/günâh galerisi" gibi gösterme eğilimindedirler. Oysaki insanın yapması veya yapmaması gereken her türlü eylem, sonuçta onun ahlâklı bir kişilik kazanımına yönelik güçlü bir katk1 sayılmalıdır. Bu yüzden de ibadetlerin kazanımını sevap-günâh ölçeği üzerinden değil, "ahlâk" ve "takva bilinci" üzerinden tanımlamak gerekmektedir. Yoksa gelecekteki maddî kazanım üzerinde odaklanmış olan bencil ve menfaatçi bir Müslüman kişiliğin oluşması işten bile değildir. 
Bazı ilmihâllerin inşâ etmiş olduğu kadın algısı, yaratılış değerleri olarak erkeklerle aynı unsur üzerinde halkedilmiş olan bir varlığ 1 değil, erkeğe itaatinin kutsandığı bir din anlayışını öne çıkarmaktadır. Kadın algısını "muhataplık" üzerinden değil de, "itaatkârlık" üzerinden tanımlamış olan bu eğilimin toplumsal barışa katkısı beklenenden az olacaktır. Bu anlayışın yedeğinde tesis edilmiş olan bir yapıdan neş'et eden herhangi bir eylem ise, sonuçta ahlâkî kazanım olarak kabul edilemez.

İlmihâller, genel olarak ait olduğu mezhebin görüşü üzerinden din anlattığg için, kabul edilebilir bir din anlayışı için sadece kendi mezhebini adres gösteren eserler olarak bilinir. Bu yüzden de gerek fikhî konularda, gerekse de itikadî konularda ortaya koydukları ilkeler, dinin asıllarıymış gibi algılanır olmuştur. Sıradan halkın dinî yaşantısı üzerinde büyük bir kolaylık sağlayan bu durum, son derece pratik olması bakımından da tercih edilmiştir. Öyle ki bu eserlerde sıklıkla bahsedilen şeyler, bütünüyle dinin asıllarıymış gibi algılanmıştır. Bahsedilmeyenler ise diğerleri gibi dikkate alınmamıştır.

İlmihâl dindarlığının ibadet yapımı üzerinden öncelediği şey, Allah rızasıdır. Hâlbuki insanın yapması istenen her türlü ibadette önceliğin bireyin kemâli ve çevresinin tanzimi olmalıdır. İlgili eserlerde anlatılan ibadetlerin amaçlarının da bütünüyle bu minvâl üzere desteklenmiş olması gerekmektedir. Hem, mâkul ölçüler dairesi içerisinde kulun rızasının olduğu her yerde, Yüce Allah'ın da rızasının olacağı normal bir gelişme kabul edilmelidir.

Mevcut ilmihâller, Müslümanların genelini kuşatıcı bir dilden yoksun bulunmaktadır. Nitekim onların kullanmış olduğu dil, genel hatlarıyla kendi değerlerini benimseyen kişiler için tanıdık gelmektedir. Bu yüzden de sıradan halkın nezdinde "bizim dinimize göre" şeklindeki ifadelerin kökeninde, ilmihâllerin öğrettiği dinsel algı yatmaktadır. Oysaki herhangi bir dinin talimatları üzerinden değer üreten ilmihâller, mezhebî yaklaşıma kurban edilmiş gibidir. Diğer bir ifadeyle "yerel", "millı̂" ve "mevẑ̂" bir dindarlık ölçeği üzerinde din anlatan ilmihâller, herkesi kucaklayıcı bir dil kullanmalı, hatta elindekini öven kutsal geçmiş anlayışını terk etmelidir. Zira bu bakış açısından ötekileri de kapsayan evrensel bir ümmet bilinci çıkmamaktadır.

Mevcut ilmihâller, "Kur'an ahlâkı" yerine önlerinde bulunan hazır bulunuşluklardan beslenmektedir denilebilir. Bu yüzden de ilgili eserlerde, adeta konsensüs sağlanmış şekilde tarihsel kazanımların aktarıldığı görülmektedir. Genel bir kabul mesabesinde olan bu yaklaşımlar, geçmiş ulemanın bakış ve çözüm şekli üzerinden dinsellik alanlarının oluşmasını temin etmektedir. $\mathrm{Bu}$ durum ise birey ve toplumun kendi çağı için öncelemesi gereken aslî şeyleri göz ard1 edebilmekte, hatta hayat kitabı olan Kur'an'1n çözümlerini de bütünüyle gölgelemektedir. Diğer bir ifadeyle kişiler, kendilerini ilgilendiren sorunlarda doğrudan Kur'an'a değil, ilmihâle başvurmak suretiyle, bahis konusu ettikleri her şeyi ilgili eserlerin himayesinde çözüme kavuşturmaktadır.

Görüldüğ̈ kadarıyla ilmihâllerin öncelediği şey, ahlâklı birey ve ahlâklı toplumdan ziyade, ibadet ve taatını eksiksiz yerine getiren mü'min bir toplum 
hayalidir. $\mathrm{Bu}$ yüzdendir ki ilmihâl dindarlığı, ahlâklı bir hayatı kuşatan içerikler/kazanımlar üzerinden değil, şeklî unsurlar üzerinden basit bir Müslümanlık tanımlamaktadır. İlgili Müslümanlığın çıktıları olarak görülebilecek ilk değer ise, inanç ve ibadetini yaptığı hâlde ahlâkî konularda büyük bir eksikliğin görüldüğü birey tipinin gelişmiş olmasıdır. Deyim yerindeyse, asgarî müştereklerin yapımı üzerinden gelişen sığ bir Müslümanlığın görünür olduğu her ortam, bu algının merkeze çekildiği dindarlıkların besleyici unsuru olarak kabul edilmelidir.

$\mathrm{Bu}$ aşamada ifade edilebilir ki ilmihâller, halk nezdinde anlatmak istedikleri dinin yerini almış olan etkin eserlerden sayılabilir. O yüzden günlük yaşamda ilmihâl denilince, bütünüyle dinden bahseden eser anlaşılmaktadır. Dahası, halkın büyük çoğunluğu dinini bu eserlerden öğrendiği için, ilmihâl ve din algısının yakınlığı, ilgili duygunun kökleşmesini sağlamış gibidir.

Ezcümle, ilmihâller, kurgusal olarak ahlâkî değerlerin kazanımından çok, inanç ve ibadetin tahsisi üzerinden din anlattıkları için, hayatın bütünü içerisinde gerçek mahsul olması gereken ahlâkî kazanımlar, bu iki değerden bağımsız bir yapıda anlaşılmış gibidir. Hâlbuki sağlıklı bir Müslüman kişiliğin inşâsı için gerekli olan iki değerin varlığ kadar, hatta onlardan daha çok bu kazanımın tahsili önemlidir denilebilir. Bu yüzdendir ki ifade edilmiş olan değerlerin hiçbiri, bir diğerinin yerini tutamaz niteliktedir. Nitekim inanç ve ibadetin içerisine serdedilmiş olan ahlâkî kazanımlar, esas olarak kişisel ve toplumsal süreçlerde kabul edilebilir bir karakter yapısının teminine yönelik bildirimler mesabesinde görülebilir.

\section{Sonuç}

Kanaatimizce din-ahlâk ilişkisinin temeli, özgürlük ve sorumluluk alanlarının tesis edilmiş olması üzerinde yükselebilir. Bu durum, insan için doğru olduğu kadar, Tanrı için de böyledir. Temeli borç kültürü üzerinde inşâ edilen bir ibadet algısının, hayatın bütününü kuşatacak güçlü bir ahlâkî kazanım üzerinde yükselmesi de pek mümkün değildir. Hâlbuki ibadî değerler, öncelikli olarak insanı eğitmek amacıyla tedavüle sürülmüsslerdir. Yani ahlâk, dinin içerisinde mümkün olan bir ibadet alanından sonra kazanılan bir değere dönüşmektedir. Mamafih bu kazanım, bittabiî olarak insanın bütün davranışlarını yönlendiren etkin bir süreci de ifade etmektedir. Ahlâkın temelde bir arınma modeli olarak kullanıldığı sûfî çevrelerde üretilmiş olan zikir formları ile bu kazanımın elde edilmesine çalışılmaktadır. Ayrıca yapılan ibadetler üzerindeki gerçek hedefin ahlâk olmadığı her ortamda, ibadetin ritüele, ritüelin de dine dönüştüğü görülmektedir. Bu durum, insan hayatını bütünüyle kuşatma eğiliminde olan bir dinin istediği gelişme değildir. Zira din, ibadeti amaç olarak gören bir ahâk öngörmemiştir. Bilakis yapılan ibadetin kazanımını herkes için genel geçer olan bir ahlâkî yapı olarak kabul etmektedir.

Zaman itibariyle Yirmi birinci yüzyıl içerisinde yaşadığımız hâlde, ilmihâllerin sunduğu bazı bilgilerin bu çağla hiçbir şekilde uyuşmadığı görülmektedir. Yüzyıllar öncesinin hijyen anlayışına uygun olan kuyu temizliği şekillerinin 
ilmihâllerde hâlâ kullanıldığı ve önerildiğini görmekteyiz. ${ }^{46} \quad$ Bu yüzdendir ki yaşanılan hayatı "din içi”" ve "din dışı" alan olarak birbirinden bütünüyle farklı kulvarlarda gören eserlerin oluşturduğu İslâm anlayışı, hayatın bütününü kapsayan total bir ahlâk üretememiştir. $\mathrm{Bu}$ durum yalnızca sosyo-ekonomik alanda değil, siyasî, dinî ve diğer bütün alanlarda da bundan farklı değildir. Hatta ilmihâllerin üzerinde 1srarla durmuş olduğu hâlde, uhrevî bir ahlâkın da oluştuğu söylenemez. Zira cennet, cehennem, hesap, ödül ve ceza algımızın bir kısmı yine bütünüyle adaletsizlik üzerine işlemektedir. Çünkü şefaat beklentisi ve kabir azabı gibi inanışlar, kesin ve âdil bir hesaptan önce yapılması muhtemel genel bir eziyeti uygun gören bir din algımızın olduğunu ileri sürmektedir. $\mathrm{Bu}$ yüzdendir ki ilgili inanışların ilâhî adalet üzere tesis edilmiş olan bir ahlâk üretmesi de mümkün görünmemektedir.

Ne yazıktır ki Müslüman kültür, uzun zamandan beri "öteki” tarafından örnek alınabilecek bir ahlâk modeli geliştirememiştir. Görünür geçmişte başkaları için örnek alınabilecek siyasî, sosyal, ekonomik hatta dinsel bir ortak ahlâk havuzumuzun olmaması, yıkıcılığın kol gezdiği günümüz dünyası için büyük bir kayıp olsa gerek. Dahası, insanlığın kurtuluşu için adeta tek seçenek olarak kalmış olan İslâm, insanlığın huzuru için gerekli olan her türlü ahlâkî umdeleri ihtiva ettiği hâlde, Müslümanların bu umdeleri içselleştiremedikleri görülmektedir. Kendi içerisinde sosyal barışı temin edemeyen bir İslâm dünyasının, başkalarına örnek olabilmesinin de şansı yoktur. Müslüman bireyler uzun zamandan beri vahiy havuzunun ahlâk umdelerinden beslenmedikleri için de başkaları nezdinde ibret alınabilecek bir toplumsal yapıyı inşâ edememişlerdir.

Sonuç olarak ifade edilebilir ki inanç, ibadet ve ahlâkî kazanımların beraberce yol aldığ 1 bir kişilik sürecinde önemsenen şey, bu üçlünün beraberce hareket ettiği sağlıklı bir kişilik yapısının oluşturulmasıdır. Mamafih bu sayede görünür her ortamda geçerli ve kabul edilebilir bir Müslüman ahlâkının yerleşmesinin temin kolaylıkla sağlanabilir. Yoksa geleneksel ilmihâl yazımının büyük bir kısmının atladığı şekliyle, bu üç değer, birbirinden bütünüyle bağımsız alanlar olarak görülmemelidir. Kanaatimizce ilmihâl yazımında başvurulacak en doğru yol, klâsik modellemede olduğu veçhile konuların ayrıştırılmasından çok, metin içerinse giydirilmesi, her ibadetin kazanımıyla birlikte ifade edilmesi, yani ahlâkın, kişilerden yapılması istenilen davranışların mutlak sonucu olduğunun gösterilmesidir. Artık, kelâmcıların ilmihâl yazmasının vakti gelmiş, geçiyor bile...

\footnotetext{
${ }^{46}$ Kuyu temizliği için ifade edilen " kuyudan şu kadar kova su çekilir” tarzındaki bir çözüm şeklinin, (Bkz. Bilmen, age, s. 59-60), bu yüzyıl içerisinde anlaşılması kolay gözükmemektedir. Zira kendi dönemi itibariyle önerilmiş olan bu çözümler, artık yerini sağlık bilimlerinin tavsiyelerine bırakması gerekmektedir. Gelinen bu aşamada artık Müslümanlar, temizlik ve hijyen için ilmihâlleri değil, sağlık kuruluşlarını göreve çağırma sorumluluğunu yakalamış olmalıdır. Dahası, temiz ve temizleyici suların tarifi de artık ilmihâllerden ziyade (Bkz. Bilmen, age, s. 55), kimyager ve sağlıkçıların iş alanında kabul edilmelidir.
} 


\section{Kaynakça}

AKSEKİ, Ahmed Hamdi, Askere Din Kitabı, DİB Yayınları, Ankara 1982; Din Dersleri, Üçdal Neşriyat, İstanbul 1970; İslâm Dini/İtikat-İbadet-Ahlâk, Nur Yayınları, Ankara 1982; Müslümana Büyük Illmihâl, Üçdal Neşriyat, İstanbul 1971; Yavrularımıza Din Dersleri, (1-4), Cumhuriyet Kitabevi, İstanbul 1947.

AKYÜZ, Vecdi, Mukayeseli İbadetler İlmihâli, (1-4), İz Yayınları, İstanbul 1995.

ALGÜL, Hüseyin, Dini Bilgiler/İslâm İlmihâli-İtikad-İbadet-Siyer-Ahlâk, Semih Ofset, Ankara 1992.

ALGÜL, Hüseyin-Apaydın, Yunus-Dönmez, İ. Kâfi-Erkal, Mehmet-Harman, Ö. Faruk-Kılavuz, A. Saim-Uludağ, Süleyman-Yücel, İrfan-Aydın, M. AkifBardakoğlu, Ali-Çağrıcı, Mustafa, İslâm İlmihâli, (I-II), TDV Yayınları, İstanbul 1998.

ALTUNTAŞ, Halil-Karagöz, İsmail, Oruç İlmihâli, DİB Yayınları, Ankara 2008.

ARPAGUŞ, Hatice Kelpetin, “İlmihal” md., TDV İslam Ansiklopedisi, İstanbul 2000; Osmanlı Halkının Geleneksel İslâm Anlayışı ve Kaynakları, Çamlıca Yayınları, İstanbul 2001.

ARVASİ, S. Ahmed, İlm-i Hâl, Burak Yayınları, İstanbul 1990.

ATAY, Hüseyin, İslâm'ın İnanç Esasları, AÜIF Yayınları, Ankara 1992; Kur'an'a Göre Iman Esaslarl, Ajans-Türk Matbaas1, Ankara ts.; Kur'an'a Göre İslâm'ın Temel Kuralları, Gelişim Matbaası, Ankara 1985.

ATEŞ, Süleyman, Yeni İslâm İlmihâli, Kılıç Kitabevi, Ankara 1979.

AYDIN, Abdullah, Tam İzâhlı Büyük İslâm İlmihâli, Aydın Kitabevi, İstanbul ts.

AYDIN, Mehdi, Kadın İlmihâli, Gönül Film Müzik Yayınları, İstanbul 2005.

AYDIN, Mehmet, İslâm Dîni İlmihâli/İtikad-İbadet-Ahlâk, Hibaş Yayınları, Konya 1984.

BELVİRANLI, Ali Kemal, İslâm Prensipleri, Nedve Yayınları, Konya 1962.

BİLMEN, Ömer Nasuhi, Büyük İslâm İlmihâli, Ahmed Said Matbaası, İstanbul 1957; Dinî Bilgiler/Sualli-Cevaplı, Bilmen Basım ve Yayınevi, İstanbul ts.

BUHARÎ, Ebu Abdullah İsmail, el-Câmiu's-Sahîh, (I-VIII), Çağrı Yayınları, İstanbul 1981.

COMTE, Auguste, Pozitivizm Illmihali, çev. Peyami Erman, MEGSB Yayınları, İstanbul 1986.

DÖNDÜREN, Hamdi, Delilleriyle Aile İlmihâli, Altınoluk Yayınları, İstanbul 2011; Delilleriyle Hac ve Umre, Erkam Yayınları, İstanbul 2007; Delilleriyle İslâm İlmihâli/İnanç-İbadet-Günlük Hayat, Erkam Yayınları, İstanbul 1991; Delilleriyle Ticaret ve İktisat İlmihâli, Erkam Yayınları, İstanbul 1993. 
EFE, Mehmet, Mizraksız İlmihâl/Romantik Deneme, Yerli Yayınları, İstanbul 1992.

ELALDI, Murat, Çocuklar İçin Din ve Hayat/İlköğretim Okulları İçin Kaynak Kitap, (1-2), Uludağ Yayınları, İstanbul 2007; Çocuklar ve Gençler Iç̧in Hayat Rehberi/Modern İlmihâl, Uludağ Yayınları, İstanbul 2010.

GÜLLE, S1dk1, Ehl-i Sünnet Ve'l-Cemaât'a Göre İslâm Akaidi ve Hanefi Fıkhına Göre İslâm İlmihâli, Akpınar Yayınevi, İstanbul 1987.

GÜRAN, Kemal, Müslümanın El Kitabı/Her Müslüman İçin Gerekli İlmihâl Bilgileri, Timaş Yayınları, İstanbul 2011.

HAÇKALI, Abdurrahman, Muhtasar İslâm İlmihâli, Başak Yayınları, Bişkek 2008.

HALEBÎ, İbrahim Efendi, Halebî Să̆îr/Babadâğ̂̀ Tercümesi, sad. İsmail Karakaya, Akçağ Yayınları, Ankara 1983.

HATİBOĞLU, Burdurlu Mehmed, Ana Kaynaklara Göre İslâm Dini/Usul ve Tatbikat, Cumhuriyet Matbaası, İstanbul 1946.

HATİ, Abdulaziz, Gençler İçin İmân ve Ahlâk Rehberi, Sebat Basım Yayım Dağıtım, İstanbul 2005.

HATİPOĞLU, Haydar, Büyük Şafii İlmihâli, Mesaj Yayınları, Ankara 1991.

IŞIK, Hüseyin Hilmi, Tam İlmihâl/Seâdet-i Ebediyye, haz. M. Sıddık Gümüş, Hakikat Kitabevi, İstanbul 2009.

İBN HANBEL, Ahmed, Müsned, (I-VI), Çağrı Yayınları, İstanbul 1981.

İMAM AZAM/EBÛ HANIFE, Numan b. Sabit, el-Fıkhu'l-Ekber, “İmam-1 Azam'ın Beş Eseri”' içinde, çev. Mustafa Öz, Kalem Yayıncılık, İstanbul 1981.

İMAM MALİK/Malik b. Enes, Muvatta, (I-II), Çağrı Yayınları, İstanbul 1981.

İSKİLİPLI, Muhammed Âtıf Hoca, Yeni İlmihâl/İslâm Yolu, sad. S. Hüküm, Nehir Yayınları, İstanbul 1991.

İSLAMOĞLU, Beşir, Modern İlmihâl/Davranış Bilgisi/İnanç, Metodoloji, İbadet ve Sosyal Hayat Fıkhı, İlâhiyât Yayınları, Ankara 2002.

İSLAMOĞLU, Mustafa, Hasan el-Basri’nin Kader Risalesi ve Şerhi, Düşün Yayınc1l1k, İstanbul 2012.

KARADUMAN, Bekir Sitk1, Hulasâtü'l-Kur'ân ve Hulasâtü'l-İslâm, (1-3), Kalkan Matbaası, Ankara 2006.

KAYA, Haydar, Bektaşi İlmihâli/Kuralları, Ayyıldız Yayınları, Manisa 1989. 
KAYA, İsmail, İslâm Dini ve İlmihâli/İtikat-İbadet-Hukuk Dua ve Mükellefin Şahsi Hal Bilgileri, Madve Yayınları, İstanbul 1994.

KAYA, Murat, Ebedi Yol Haritası Íslâm, Altınoluk Yayınları, İstanbul ts.

KESKİN, Mehmet, Büyük Şafii İlmihâli, Semerkant Yayınları, İstanbul 2005; Caferi İlmihâli, DİB Yayınları, Ankara 2010; Dört Mezhebe Göre İslâm İlmihâli, Çağrı Yayınları, İstanbul 2012; İslâm İlmihâli/Iman-İbadetler-Helaller-Haramlar, Çağrı Yayınları, İstanbul 2006.

KIRBAŞOĞLU, M. Hayri, Ahir Zaman Ilmihali, OTTO Yayınları, Ankara 2011.

KISAKÜREK, Necip Fazıl, Iman ve İslâm Atlası/Şekil-Ruh-Amel-Hikmet, Büyük Doğu Yayınları, İstanbul 1981.

KÖKSAL, Mustafa Âsım, İlmihâl/Müslüman Çocuklarına Din Bilgisi, Yıldız Matbaası, Ankara 1957; İslâm İlmihâli, İrfan Yayınları, İstanbul 1977.

KÜÇÜKER, Ali, İslâmî Hikmet ve Öğ̈üter, (1-2), Anıl Matbaası, Ankara 2008.

MIZRAKLI ILMİHÂLl, haz. M. İsmail Fındıklı, Yasin Yayınevi, İstanbul ts.

MUHAMMED ALİ, Mevlanâ, İslâm Dini/Kaynaklar-İbadetler-İnançlar, çev. Ömer Aydın, İşaret Yayınları, İstanbul 2007.

MÜFTÜOĞLU, Atasoy, Travmatik Varoluşlar, Yeni Şafak, 2. 12. 2013.

ÖĞÜT, M. Cemal, Kadın İlmihâli, Huzur Yayınları, İstanbul 2006.

ÖNGÜT, Ömer, Kalplerin Anahtarı İslâm İlmihâli, Hakikat Yayınları, İstanbul 2004.

ÖZTÜRK, Mustafa, Kur'an-ı Kerim Meali/Anlam ve Yorum Merkezli Çeviri, Ankara Okulu Yayınları, Ankara 2014.

PİLAVOĞLU, Mehmed Kemal, Din Rehberi, Pilavoğlu Kitabevi, Ankara ts.; Müslüman Çocuğun Din Kitabı, Yargıçoğlu Matbaası, Ankara 1964; Müslüman Kızın Din Kitabı, Çelik Yayınları, İstanbul 1983.

SOFUOĞLU, M. Cemal, İslâm Dini Esasları, İzmir İlâhiyat Fakültesi Vakfı Yayınları, İzmir 1999.

SOYMEN, Mehmet, Cep İlmihâli, DİB Yayınları, Ankara 1979; Dinî Bilgiler, DİB Yayınları, Ankara ts.

SÖZERİ, M. Sabri, Mehmetçiğe Din Dersleri/Iman-İbadet-Ahlâk, Fakülteler Matbaas1, İstanbul 1965.

ŞENTÜRK, Lütfi-Yazıcı, Seyfettin, İslâm İlmihâli, DİB Yayınları, Ankara 2009.

TANTAVİ, Ali, İslâm Dini, çev. Ömer Dönmez, Pamuk Yayınları, İstanbul 2000. 
TEMEL, Nihat, Kur'an Aydınlı̆̆ında Müslümana Yol Haritası, Ensar Neşriyat, İstanbul 2006.

TOPÇU, Nurettin, İsyan Ahlakı, Dergâh Yayınları, İstanbul 2006.

UCA, İsmail Hakkı, Delil ve Kaynaklarıyla Büyük Kadın İlmihâli, İpek Yayınları, İstanbul 2003.

ULUŞAN, Talip, Kaynaklara Dayalı İlmihâl, Ankara 2004.

ÜNLÜKUL, Abdulmecid, D̂̂-Mezhebi (İki Mezheb) Adlı Bir İlmihâl, İleri Basımevi, Konya 1962.

YAVAŞ, Hasan, Namaz Kitabı, Hakikât Kitâbevi, İstanbul 2008; Rehber İlmihâli, İstanbul 2009. 